\title{
Volcaniclastic sedimentation on the submarine slopes of a basaltic hotspot volcano: Piton de la Fournaise volcano (La Réunion Island, Indian Ocean)
}

\author{
Francky Saint-Ange ${ }^{\mathrm{a}, \mathrm{b}, \mathrm{d}, *}$, Patrick Bachèlery ${ }^{\mathrm{c}, \mathrm{d}}$, Nathalie Babonneau ${ }^{\mathrm{e}}$, Laurent Michon ${ }^{\mathrm{d}}$, \\ Stephan J. Jorry ${ }^{f}$
}

\footnotetext{
a Geological Survey of Canada (Atlantic), Bedford Institute of Oceanography, P.O. Box 1006, Dartmouth, Nova Scotia, Canada B2Y 4A2

${ }^{\mathrm{b}}$ Department of Oceanography, Dalhousie University, Halifax, Nova Scotia, Canada B3H 4J1

c Laboratoire Magmas et Volcans, UMR 6524, Université Blaise Pascal, CNRS, Clermont-Ferrand, France

d Laboratoire Géosciences Réunion, Université de la Réunion, Institut de Physique du Globe de Paris, CNRS, UMR 7154, 15 avenue René Cassin, 97715 Saint Denis cedex 9, France

e Université de Brest, CNRS UMR 6538 Domaines Océaniques, IUEM, Place Nicolas Copernic, 29280 Plouzané, France

f IFREMER, Géosciences Marines, Laboratoire Environnements Sédimentaires, BP70, 29280 Plouzané, France
}

\author{
*: Corresponding author : Francky Saint-Ange, tel.: + 19024268988 ; \\ email address : Francky.Saint-Ange@NRCan-RNCan.gc.ca
}

\begin{abstract}
:
Volcaniclastic successions are well-described in volcanic arc setting but rare in hotspot environments. The present work proposes a facies model of volcaniclastic sedimentation related to basaltic hotspot volcanoes as exemplified by the Piton de la Fournaise volcano (La Réunion Island). The facies model is based on a multi-scale approach combining high-resolution multibeam and backscatter data, deepwater photographs, side scan imagery and Kullenberg piston cores. Data show that a wide range of gravity flows and erosional features develop in the active volcaniclastic sedimentary system. Coastal and submarine instabilities are the main processes shaping the volcano's submarine morphology. Meanwhile, the evolution and dynamics of the sedimentary system are strongly linked with the morpho-structural evolution of the subaerial part of the volcano. The proposed model is characterized by a cyclic succession of stages: (1) a growing stage during which sedimentary activity is mainly restricted to proximal and mid-slope areas; (2) a collapse stage that entirely reshapes the morphology of the submarine slopes; and (3) an erosional stage related to a slow down of volcanic activity, enabling the development of large deep-sea fans.
\end{abstract}

\section{Graphical abstract}

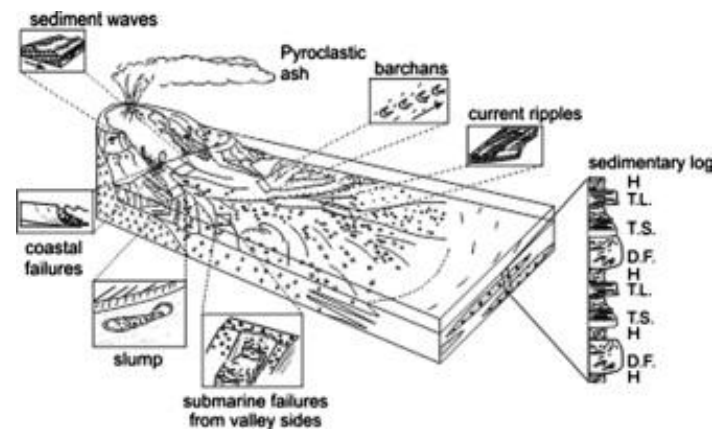




\section{Highlights}

Facies model of volcaniclastic sedimentation related to basaltic hotspot volcanoes. Active volcaniclastic sedimentary system in the proximal area. Gravity flows are related to recurrent coastal and submarine failures. Volcaniclastic sedimentation depends firstly on volcano-tectonic activity. The proposed model is characterized by a cyclic succession of stages.

Keywords: turbidites ; debris avalanche ; landslide ; erosion ; volcano ; La Réunion Island

\section{Introduction}

Volcaniclastic sediments are defined as volcanic rock fragments produced during or after a volcanic event (Fisher, 1961; Carey and Schneider, 2011). Volcaniclastic sediments include autoclastic, pyroclastic and epiclastic types, formed by fragmentation, volcanic explosions or weathering and erosion. These terms are important, as from these distinctions, facies model will emerge to be used as a base for future observations and as a guide for comparisons with new or different geological settings (Walker, 1984; Allen et al., 2007; Manville et al., 2009). Volcaniclastic sedimentary processes have been mainly studied in back-arc and island-arc settings; (1) because volcanic processes represent a major input of clastic material to the basin, and (2) because of the need for modern analogues to help understand ancient successions that are of economic interest (Manville et al., 2009).

Different facies models defined for ancient series in island arc settings show that sedimentary successions in volcaniclastic slope aprons are often thick, e.g. up to 3000-mthick for Kalgoorlie Archean sequences (Krapež and Hand, 2008). In the different models, apron successions are defined as an interstratification of volcanic breccias, volcaniclastic turbidites (epiclastic and/or pyroclastic), debris flows and hemipelagic sediments (Busby, 1988; Màngano and Buatois, 1997; Krapež and Hand, 2008). In some cases, welldeveloped turbidite systems with channel-levees complex are observed (Krapež and Hand, 2008).

In contrast to island arcs, volcanic islands in hotspot settings do not experience frequent explosive eruptions but instead are characterized by large scale flank failures generating thick debris avalanche deposits (Moore et al., 1989; Masson et al., 2002; Oehler et al., 2008). Thus, the accumulation of such breccias is considered as an important building process for basaltic volcanoes. It follows that facies models developed for arc settings cannot be directly used for hotspot settings. Furthermore, the few studies carried out on basaltic shields mostly use volcaniclastic successions as a proxy to differentiate the submarine stage from the shield stage and the collapse/erosional stage (Walker, 1990; Schmincke and Sumita, 1998), instead of determining specific sedimentation models.

The objective of the present work is to introduce a facies model of volcaniclastic sedimentation in an active hotspot setting through the example of Piton de la Fournaise volcano. This work aims at revisiting and assessing deep-water volcaniclastic processes related to the Quaternary volcano-tectonic and geomorphologic evolution of the volcano. We first describe the transition zone between onshore and offshore domains in order to subsequently understand its role in deep-water sedimentary processes. Secondly, we present the wide range of sedimentary deposits and processes encountered on the submarine slopes. Finally, we propose a facies model based on the volcaniclastic apron of Piton de la Fournaise volcano that can be generalized to other active oceanic basaltic volcanoes. 


\section{Geological setting}

La Réunion Island is located in the Mascarene Basin (Indian Ocean), $700 \mathrm{~km}$ East of Madagascar. It is the most recent surface expression of a mantle plume that created the Deccan Traps, the Mascarene Plateau and Mauritius Island (Duncan, 1990). The 7-kmhigh edifice of La Réunion results from magmatic activity which initiation on the oceanic floor is estimated at 5-8 Ma (Bonneville et al., 1988). Piton de la Fournaise, the current active volcano of La Réunion, has been built on top of a pre-existing volcanic edifice since 450 ka, named Les Alizés (Lénat et al., 2001; Merle et al., 2010; Smietana, 2011). Bathymetric and geophysical data suggest that Les Alizés experienced several flank destabilizations that fed voluminous debris avalanche deposits (Oelher et al., 2008; Gailler and Lénat, 2010).

Since $450 \mathrm{ka}$, Piton de la Fournaise underwent successive building stages interrupted by intense erosion and caldera collapses (Mairine and Bachèlery, 1997; Merle et al., 2010). The occurrence of widespread debris avalanche deposits on the submarine flanks suggests that the volcano was also affected by several major flank landslides whose ages remain poorly constrained (Lénat et al., 1989; Bachèlery et al. 1996; Labazuy, 1996; Oehler et al., 2008). Five K/Ar dates of subaerial blocks constituting the debris avalanche deposits give ages of $12 \mathrm{ka}, 45 \mathrm{ka}, 62 \mathrm{ka}, 68 \mathrm{ka}$ and $1.8 \mathrm{Ma}$ (Figure 1; Lénat et al., 2009). The deposits show three axis of deposition: a main one trending W-E and two secondary ones along the SW-NE and NW-SE directions. These debris avalanches are cut by wide, shallow depressions with abrupt walls (Figure 1). They developed around the Plateau Sous-Marin Est, except for the Couloir Dolto that incised this bulge. Valleys are short (15-30 km average length) and more developed on the northeastern side of the Plateau Sous-Marin Est than to the southeast (Figure 1). Among the valleys, only the Chenal Vincent is connected to the shore. The other depressions, starting from a few kilometers to $25 \mathrm{~km}$ offshore (Figures 1 and 2), were interpreted as the scars of submarine instabilities (called secondary instabilities by Oehler et al. (2008).

The modern activity of Piton de la Fournaise is now located within a U-shaped structure bounded by two short and diffuse rift zones trending in NE and SE directions. This depression, named Enclos Fouqué/Grand Brûlé, might correspond to a 4.5-ka-old scar resulting either from a combination of coalescent caldera collapses and an eastward flank destabilization (Bachèlery, 1981), or from a single, large flank destabilization (Duffield et al., 1982; Labazuy, 1991; Oehler et al., 2004), from a hybrid collapse mechanism characterized by edifice deformation on low strength hydrothermal cores (Merle and Lénat, 2003). On the submarine flanks, the structure that would result from the lateral collapse of the Grand Brûlé is the Chenal Vincent and the related deposits are named the Ralé Poussé (Figure 1 and 2). However, recent work based on a detailed morpho-structural analysis and a reappraisal of sub-aerial geological data proposes that the lower part of the U-shaped structure, i.e. the Grand Brûlé, does not result from a lateral destabilization 4.5 to $10 \mathrm{ka}$ ago, as previously suggested, but from a slow vertical collapse (Michon and Saint-Ange, 2008). Indisputably, questions consequently remain on both the age and the origin of the Chenal Vincent and the Ralé Poussé deposit, and, on the whole, about the origin of the Enclos Fouqué/Grand Brûlé depression (Bachèlery and Michon, 2010).

The volcanic activity of Piton de la Fournaise is now characterized by frequent small volume eruptions (Peltier et al., 2009). Episodically, larger eruptions occur, leading to the 
building of coastal platforms. During the large 2007 eruption, $\sim 230.10^{6} \mathrm{~m}^{3}$ of lava were emitted (Bachèlery et al., 2010) and a platform of $0.45 \mathrm{~km}^{2}$ developed (Staudacher et al., 2009). Erosion of the platforms by wave action subsequently produces coarse-grained sediments that feed turbidity currents (Ollier et al., 1998). Initially, the volcaniclastic slope apron of Piton de la Fournaise was considered as a sedimentary fan (Cochonat et al., 1990; Ollier et al., 1998). However, multibeam data showed that the fan mostly corresponds to debris avalanche deposits (Oehler et al., 2004; 2008). A dynamic sedimentary system has only been recognised close to the shore. The lack of finegrained sediment was interpreted as related to the lack of rivers in the subaerial area (Ollier et al., 1998).

\section{Data set}

The data presented in this paper were collected during three different cruises: FOURNAISE 2 (1988), FOREVER (2006) and ERODER leg 1 (2006). Side-scan data (180 kHz; $4 \mathrm{~m}$ resolution), deep water photographs and 11 Kullenberg piston cores (KF) were collected during the FOURNAISE 2 cruise (Ollier et al., 1998). Multibeam and backscatter data and cores KERO-05 and 06 were obtained during FOREVER (EM 12D sonar) and ERODER leg 1 (EM 120 sonar; Figures 1 and 2). Three digital elevation models (DEM) at different resolutions were processed: a regional DEM at $150 \mathrm{~m}$ pixel resolution (Figure 2), a DEM at $50 \mathrm{~m}$ resolution for water depths ranging from 500 to $3500 \mathrm{~m}$ (Figures 1 and 2), and a DEM at $25 \mathrm{~m}$ resolution for the proximal area (Figures 3 and 4). No measurements of physical properties were available for cores collected during Fournaise 2. Photographs were redone on all cores and $1 \mathrm{~cm}$ slabs were taken when possible for X-ray images. Grain size analysis was carrying out on turbidites using a Coulter laser LS130.

\section{Results}

\subsection{Onshore - offshore transition}

Our understanding of the origin of the sub-aerial and submarine structures, especially how they link, requires that the processes working at the transition between the two domains be well constrained. Onshore, five main geological structures are identified (Figure 3). To the North, the Ravine Ferdinand is an E-W trending scarp interpreted as the northern limit of a large flank destabilisation (Bachèlery, 1981; Merle and Lénat, 2003; Oelher et al., 2008). The Bois Blanc scarp and the Osmondes paleo-valley correspond to erosion structures, as evidenced by the lobate geometry of the scarp and the thick alluvial deposits encountered in drillholes south of the scarp (Kieffer, 1990; Courteaud, 1996; Michon and Saint-Ange, 2008). The Osmondes paleo-valley and the Grand Brûlé currently form a large depression, the surface of which is recurrently covered by lava flows. The largest ones may build lava platforms in the shore. The Tremblet scarp corresponds to the southern boundary of the depression and is interpreted as a tectonic structure; either the southern limit of an eastward flank landslide (Bachèlery, 1981; Duffield et al., 1982; Labazuy, 1996; Oehler et al., 2008) or the rim of a widespread subsiding zone (Michon and Saint-Ange, 2008). 
Offshore, bathymetric data and backscatter images allow the identification of seven units (Figure 3). To the north, the submarine part of the NE rift zone forms a massif with a smooth surface (Figure 3 and 4). The massif is limited to the south by an E-W trending 100-200-m-high scarp, which is aligned with the Ravine Ferdinand scarp (Figure 3). The Northern Corridor is characterized in the upper slopes by a smooth area with a high amplitude signal in the backscatter images. Downslope small channels develop and merge quickly (Figure 4). The Chenal Vincent corresponds to a wide valley developed eastward of the Grand-Brûlé (Figure 3 and 4). A dense network of small channels is observed within the valley. Between the Chenal Vincent and the SE Rift Zone, a field of blocks forms the Formations Occidentales (Figure 3 and 4). The blocky facies is clearly visible on both the bathymetry and the backscatter data where they show a mottled acoustic facies with very high acoustic amplitude (Figure 4). These deposits extend 12 $\mathrm{km}$ offshore and onlap the Plateau sous-marin Est. The blocks lie in a depression characterized by a smooth floor and a low amplitude acoustic signal (Figure 4). It is worth noting that the Formation Occidentales do not show any morpho-structural continuity with onshore structures (Figure 3 and 4). The southernmost structure corresponds to a southern scarp, which seems to be in continuity with the Tremblet scarp. Two particular features are observed within the Northern Corridor and the Chenal Vincent. In the backscatter data, these structures are characterized by a high amplitude mottled acoustic facies with distinct edges (Figure 4). This facies is similar to the ones observed by Mitchell et al. (2008) in the Acores Archipelago on lava deltas. We consequently propose that both structures correspond to two lava flow deposits named the northern lava delta and the median lava delta. These deltas are built on the upper slopes from the shore to $900 \mathrm{~m}$ bsl (Figure 3 and 4).

\section{2- Sedimentary environments}

\subsubsection{Erosional features and sedimentary objects from side scan sonar imagery}

Side scan sonar data enable the identification of a wide range of metre-scale sedimentary structures on the submarine slopes of Piton de la Fournaise. These structures are mostly observed within the valleys, but also on top of debris avalanche deposits (Figure 5).

Our data set reveals the occurrence of shallow slump scars on the floor of Pente Citron Galets (see Figure 1 for location). They are developed between 1300 and $1600 \mathrm{~m}$ bsl where slope values range between 2 and $2.5^{\circ}$ (Figure $5 \mathrm{~A}$ ). The two slump scars shown on Figure 5A cover a minimum area of c. $2.710^{5} \mathrm{~m}^{2}$ and $2.210^{5} \mathrm{~m}^{2}$, respectively. These structures show a main slump scar, within which rotated blocks are observed. Most slide scars are found along the flanks of Pente Citron Galets, but a few are also observed along the flanks of Couloir Dolto and Dépression Nord. These scars are $500 \mathrm{~m}$ to $1 \mathrm{~km}$ wide, often coalescent, and developed on slopes from 6 to $10^{\circ}$ (Figure $5 \mathrm{~A}$ and $\mathrm{B}$ ). Furrows of a few meters to $10 \mathrm{~m}$ wide and $500 \mathrm{~m}$ to $1 \mathrm{~km}$ long are also observed on the submarine slopes of Piton de la Fournaise (Figure 5). They are found on valley floors and are particularly abundant in the Chenal Vincent (Figure 5D) and the Dépression Nord. They are parallel to the valley axis and show a distinct high amplitude facies that contrasts with the surrounding area. As for furrows, scours are observed on valley floors (Figure 5). Two types of scours can be identified: normal scours and giant scours. The so-called normal scours show sizes ranging from 20 to $50 \mathrm{~m}$ wide and 100 to $200 \mathrm{~m}$ 
long. The giant scours are $600 \mathrm{~m}$ wide and $2 \mathrm{~km}$ long (Figure $5 \mathrm{C}$ ). A field of sediment waves is developed within the Chenal Vincent and Pente Citron Galets close to the shore (Figures 5B and 5D; Ollier et al. (1988)). Their development coincides with changes in slope angle from $8^{\circ}$ to $3.5^{\circ}$. Three types of sediment waves can be defined: symmetric, asymmetric and barchan-like waves, hereafter named barchanoids since the term barchan is restricted to eolian structures (Figures 5D and 5E). The symmetric ones develop between 700 and $1000 \mathrm{~m}$ bsl and are organized as a succession of waves parallel to each other (Figure 5D) with crests orientated perpendicular to the slope. They are 3 to $4 \mathrm{~m}$ high with wavelengths ranging between 10 and $50 \mathrm{~m}$. The asymmetric sediment waves are observed between 950 to $1050 \mathrm{~m} \mathrm{bsl}$, more or less oblique to the slopes. Their amplitude is about 3 to $4 \mathrm{~m}$ with a wavelength of about $70 \mathrm{~m}$ (Figure 5D). Barchanoids are also observed (Figure 5E). They are individual sedimentary bodies showing a crescent-like shape and are organized in a linear fashion. Horns of barchanoids point to flow direction. Here, the barchanoids are 20 to $150 \mathrm{~m}$ wide and 1 $\mathrm{m}$ high, and their wavelength varies between 50 and $70 \mathrm{~m}$ (Figure 5E).

\subsubsection{Sea-floor sediments characteristics from high-resolution photographs}

Bottom photographs taken around the Formations Occidentales show a widespread gravely area with gravels ranging in size from granules to cobbles and boulders (Figures $6 A$ to $6 D$ ). Photos $A$ and $B$ on Figure 6 show fields of gravel of volcanic origin, many scoriaceous, a few being oxidized. Some of these elements have been described as aphyric basalt and olivine basalt (Lénat et al., 2009; Figures 6C and 6D). Overall, the sediment appears to be totally unconsolidated and the fine-grained sediment content is not significant. Coarse sediments are angular, whereas smaller sediments seem to be subangular to subrounded (Figures 6A to 6D). These morphometric characteristics suggest a recurrent reworking of the smaller sediment fraction.

Bottom photographs taken around the Plateau Sous-Marin Est and the Ride de La Drague (Figures 6E to $6 \mathrm{G}$ ) on formations interpreted as debris avalanche deposits (Oehler et al., 2008) show blocks locally supported by a consolidated matrix (Figures 6E and $6 \mathrm{G}$ ). Blocks are angular to sub-angular and can be metre-sized. No sample has been taken in this area, but these blocks, consisting of massive volcanic facies, look different from those described around the Formations Occidentales. They are partially covered with fine sediments that could be hemipelagic.

In the Chenal Vincent, photos reveal gravely sand current ripples that consist of volcanic and bioclastic elements (Figure 7A). Volcaniclastic elements appear dark whereas bioclastic elements are light in color. The darker stripes correspond to the stoss side of the ripples and the light stripes to the lee sides. These ripples are observed in the sediment wave area. The current ripples have a wavelength of about $50 \mathrm{~cm}$ and amplitude ranging from 5 to $10 \mathrm{~cm}$ (Figure 7A). The outer part of the Chenal Vincent shows a wide area covered by sands and gravels, partially draped by muddy sediment interpreted as hemipelagic. The coarse fraction appears to be subrounded to rounded. Gravels are 1 to $3 \mathrm{~cm}$ in diameter, but locally up to $10 \mathrm{~cm}$ (Figure 7E). Downstream of the Chenal Vincent, current ripples are also observed (Figure 7B). Their wavelength is from 10 to $30 \mathrm{~cm}$ and their amplitude varies from 5 to $10 \mathrm{~cm}$. The sediment seems to be finer than for the ripples observed upstream on Figure 7A. Small current ripples are also observed on the floor of the Vallée des Gorgones (Figures 7C and 7D). Here, the ripples appear to be slightly sigmoidal. Their wavelength ranges from 10 to $30 \mathrm{~cm}$ with an 
average amplitude of $\sim 5 \mathrm{~cm}$ (Photos $C$ and $D$ in Figure 7 ). Down to the valley, the wavelength stays around $10 \mathrm{~cm}$ or less and the ripples start to be disorganized. Overall, the current ripples seem undisturbed by any high biological activity (bioturbation). This may suggest a recent formation.

The floor of the Dépression Nord drastically contrasts with the other valley floors (Figures 7E and 7F): it appears to be totally draped by hemipelagic sedimentation, and benthic organisms are observed (photo $F$ in Figure 7). This suggests that this area has not been hydrodynamically active for a long time compared with the other neighboring valleys.

\subsection{Core analysis}

All cores show coarse to very coarse sediments (Figures 8 and 9). Some cores are gravel-rich and pebbles are common. Because of the nature of the sediments, cores are short ( 1 to $2 \mathrm{~m}$ on average), the longest being core KF04 at $5.7 \mathrm{~m}$ (Figure 9).

Cores KF02 and KF09 are located in the Dépression Nord and Vallée du Ralé-Poussé areas respectively (Figure 2). They show normally graded beds fining from pebbles and gravels at the base to fine laminated sand at the top (Figure 8), ending with a 5 to $10 \mathrm{~cm}$ thick layer of hemipelagic sediments (Figure 8). Pebble and gravel clasts are clearly subrounded to well rounded, up to $3 \mathrm{~cm}$ in size (Figure 8), and are composed of subaerial elements such as olivine basalts, aphyric basalts, feldspar-phyric basalts, and scoria. Such sediment facies are very similar to what would be observed in areas with a river influence.

Cores KF10, KF14, KERO-05 and KERO-06 show subangular coarse-grained sediments including sands, pebbles and large mud clasts. They lack fine-grained sediments. In KERO-05 and KERO-06, sands and gravels are mixed together whereas KF10 and KF14 show normally graded sediments. No hemipelagic sediments are observed on top of the cores, which is consistent with observations made from the side scan data and photos.

Cores KF03, KF04, KF05 and KF07 show a very different sediment record. Except for KF07, which was taken at the foot of the NE Rift Zone, the three other cores are from distal areas (Figure 2). They present a succession of stacked turbidites, mostly composed of silty and sandy beds (Figures 8 and 9). Debris flow deposits are locally observed (Figure 9). Sediments are mostly composed of volcanic detritus. Plant fragments are observed in core KF07. Cores KF04 and KF05 penetrated the top of a debris avalanche deposit. Three distinct units are thus observed in core KF04. The core top consists of a 50-cm-thick hemipelagic deposit overlaying two stacked Bouma sequences about a meter thick each (Figure 9). The basal part of the core comprises debris avalanche deposits, in which rotated structures and sheared sediment are observed.

Previous stratigraphic works done on several cores, and based on planktic foraminifera and nannofossil assemblages including Emiliana huxleyi, Pseudoemiliana lacunosa, Globorotalia menardii and Globorotaria truncatulinoides (Ollier et al., 1998), show that hemipelagic sedimentation has continued since the beginning of the Holocene in most parts of the volcaniclastic apron, except in the proximal area (Figures 4 to 8 ). The debris avalanche deposit recorded in core KF04 seems to have occurred sometime between 
$270 \mathrm{ka}$ and $450 \mathrm{ka}$. Nevertheless, this left a significant gap between 12 ka and $270 \mathrm{ka}$, which is not possible to fill with the available data set.

\section{Discussion}

\subsection{Review of the sedimentary structures and their related hydrodynamic processes}

\subsubsection{Coarse-grained sediment waves}

Coarse-grained sediment waves are found around $\sim 750 \mathrm{~m}$ bsl and show wave train structure. In other contexts, this type of structure is interpreted as controlled by the channel topography as well as by a heterogeneous and limited sediment budget (Wynn et al., 2000). Changes in wave morphology and occurrence between $750 \mathrm{mbsl}$ and 1000 mbsl suggest a significant evolution in the behavior of density currents, probably related to hydraulic jumps due to the rapid change of the slope angle from $8^{\circ}$ to $3.5^{\circ}$. The coarse-grained sediment waves observed here on the slopes of Piton de la Fournaise are similar those described in the El Juan and Icod channels in the Canary Islands (Wynn et al., 2000; Wynn et al., 2002b), and in the Stromboli canyon (Kidd et al., 1998). In these three examples, the coarse-grained sediment waves have similar amplitudes to the ones described here. Nevertheless, the wavelengths are different, being 400 to 1200 $\mathrm{m}$ in the Canaries, 20 to $200 \mathrm{~m}$ at Stromboli and 10 to $70 \mathrm{~m}$ here. More striking similitudes are found with the coarse-grained sediment waves described on the Laurentian fan (Piper et al., 1985; Hughes Clarke et al., 1990; Shor et al., 1990). In this context, wavelengths range from 15 to $70 \mathrm{~m}$ and amplitudes range from 5 to $10 \mathrm{~m}$ (Hughes Clarke et al., 1990). This type of sediment waves is usually described in channelized by-pass areas (valley or channel) where slope gradient are decreasing from $12^{\circ}-8^{\circ}$ to $3^{\circ}-1^{\circ}$ (Hughes Clarke et al., 1990; Piper and Kontopoulos, 1994; Klaucke et al., 2000; Wynn et al., 2002b; Ponce and Carmona, 2011; Cartigny et al., 2011). On the proximal submarine part of the Piton de la Fournaise, the coarse-grained sediment waves are observed in a non-channelized area, but their location appears to be controlled by very shallow corridors that probably prefigure the location of future channels. The similarity between the coarse-grained sediment waves from such different environments suggests that rapid changes in slope gradient as well as small-scale topographic changes are primary factors controlling the development and location of sediment wave fields. Analog modeling results suggest that the formation, shape and behavior of sedimentary reliefs depend on a non-linear relationship between sedimentary flux and topography (Jerolmack and Mohrig, 2005). In other words, the location and development of sedimentary structures do not strictly and solely depend on the sediment flux but rather more on the resulting interaction between the topography and the flow. Wynn et al. (2002b) suggest that recurrence of low density turbidity currents leads to significant reworking of the sediment, which induces a progressive modification of the sediment waves' morphology from symmetric to asymmetric. This process could explain the evolution of the sediment waves in the Chenal Vincent from symmetric to asymmetric. The size and nature of the coarse-grained sediment waves suggest high velocity density currents. By analogy with published work, we can estimate velocities from around few $\mathrm{m} . \mathrm{s}^{-1}$ up to $10 \mathrm{~m} \cdot \mathrm{s}^{-1}$. 


\subsubsection{Barchanoids}

Barchanoids are observed several kilometers downslope from the coarse-grained sediment waves, between 1175 and $1725 \mathrm{mbsl}$. There is no connection between the barchanoids and the coarse-grained sediment waves. The former are organized in groups in which individual elements are isolated from each other (Figure 5E). The current velocity required to form barchanoids is less than for classical sediment waves, ranging from 0.20 to 0.80 m.s ${ }^{-1}$ (Kenyon and Belderson, 1973; Wynn et al., 2002a).

Barchans are mostly studied on land (Hersen, 2005; Livingstone et al., 2007). In marine environment barchanoids are associated with bottom currents on continental shelf (Todd, 2005), or continental slopes (Habgood et al., 2003; Kenyon and Belderson, 1973; Wynn et al., 2002a). Barchanoids are commonly observed in areas where currents are unidirectional and are developed on hard substrates where the sediment supply is limited but continuously renewed (Hersen, 2005; Livingstone et al., 2007).

Ollier et al. (1998) considered that in the case of the Piton de la Fournaise, the barchanoids were the last step in the evolution of the different sedimentary features observed from upslope to downslope. This implies that the development and evolution of sedimentary bedforms depends on the sediment load as well as the velocity of density currents. Thus, as velocity decreases with distance, the symmetric sediment waves evolve into asymmetric sediment waves and then into barchanoids. Various works have suggested that the evolution of the different types of sediment waves firstly depend on local sediment reworking rather than sediment load itself (Wynn et al., 2002a; Hersen, 2005; Jerolmack and Mohrig, 2005; Livingstone et al., 2007). Therefore, in the case of Piton de la Fournaise, we suggest that the presence of barchanoids is due to local conditions, i.e. hard substratum and reworking of local sediments by low density currents. They do not represent an end-member of the sediment waves family as suggested by Ollier et al. (1998).

\subsubsection{Current ripples}

The distribution and orientation of current ripples on valley floors suggests that density currents cross the entire area covered by the debris avalanche deposits. They are evidence for late Holocene activity in the Chenal Vincent, the Rale Pousse and the Vallée des Gorgones, whereas the Dépression Nord shows no sign of activity during the Holocene. The proximal area is covered by sands and gravels (Figures 6 and 7) whereas the distal part shows finer grained sediment (Figure 6). This proximal - distal evolution suggests that the velocity of density currents quickly decreases as they enter the valleys. The sandy-gravelly ripples observed in the Ralé Poussé area suggest that this area was particularly active. Current ripples of this type develop under current velocities of 0.15 to $0.5 \mathrm{~m} . \mathrm{s}^{-1}$ (Ashley et al., 1982; Wynn et al., 2002a). The current ripples observed in the Chenal Vincent developed in the area of the coarse-grained sediment waves. The contrast of velocity between the ripples and the sediment waves suggests that the current ripples are related to reworking of surficial sediment. 


\subsubsection{Scours and furrows}

The valleys show erosive floors characterized by scours and furrows of different sizes (Figure 5). These erosive features are observed in either proximal or distal areas. They are commonly interpreted as evidence for frequent turbidity currents (Shor et al., 1990; Piper and Kontopoulos, 1994; Kidd et al., 1998; Arzola et al., 2008).

Furrows are formed in area of recurrent strong turbidity currents that erode the valley floor (Flood, 1983). Scours are local grooves in the sea floor characterizing a change in turbidity current behavior, related to local topographic changes, slope angle modifications or spreading of the turbidity currents, off a channel for example (Shor et al., 1990; Piper and Kontopoulos, 1994; Arzola et al., 2008). In the case of Piton de la Fournaise, the distribution of the scours and the lack of significant topographic highs within the valleys, suggest that the scours are probably related to rapid changes in the slope locally inducing an increase in flow turbulence.

\subsection{Types and origin of gravity flows}

\subsubsection{Rocky gravity flow}

Sedimentary facies observed on photos A to D of Figure 6 correspond to widespread gravels, pebbles and blocs. These rather angular and poorly sorted elements are transported by traction. The lack of matrix and fine-grained sediment associated with these deposits is striking. It implies rapid and efficient mixing with ambient water. These deposits have been identified as having a subaerial origin (Cochonat et al., 1990; Labazuy, 1996; Ollier et al., 1998; Lénat et al., 2009). This suggests that these deposits resulted from rocky gravity flows, probably from coastal instabilities. Even though the different described areas are geographically close, they show distinct facies, suggesting recurrent local processes probably also associated with local reworking of sediments.

Rocky gravity flows are sediment processes including rock falls, rock avalanches and rockslides (Blair and McPherson, 1999). Facies described here correspond to rock falls and rock avalanches. They have similar grain size characteristics ranging from sands to blocks hectometric in scale. Published data show that rocky gravity flows can spread out over large areas (Crandell and Fahnestock, 1965; Mulder and Cochonat, 1996; Blair and McPherson, 1999; Canals et al., 2004; Arzola et al., 2008). Rock falls and rock avalanches are distinguished by the competence of the flow and the volume of sediment transported (Blair and McPherson, 1999). Rock avalanches are more voluminous than rock falls, and have a higher transport capacity. The limited amounts of data available on the submarine slopes of Piton de la Fournaise do not allow a clear distinction to be made between these two processes. They likely co-existed and probably occurred in historical time.

\subsubsection{Granular flow}

Cores KF10, KF14, KERO-05 and KERO-06 show thick units of unsorted or poorly sorted sands and gravels in which mud clasts are observed (Figure 8 and 9). Ollier et al. (1998) suggested that the sedimentary sequences observed in KF10 and KF14 were 
deposited by high-density tractional turbulent flows. The four cores listed above do not show the presence of fine or very fine grained sediments. This suggests that here the resistance to flow does not depend on the matrix but on the interstitial fluid. The lack of sorting in KERO-05 and KERO-06 and the poor sorting in KF10 and KF14 suggest that the flow was mainly laminar rather than turbulent. The poor sorting in KF10 and KF14 also suggests that these units could represent the transition from a laminar flow to a turbulent flow.

The sediment characteristic suggests that these sequences are related to granular flow. For this type of gravity flow, sediment motion is maintained by pore-fluid pressure applied by the ambient water between the grains (Lowe, 1976; Mulder and Cochonat, 1996; Stow and Johansson, 2000; Iverson and Vallance, 2001; Shanmugam, 2002). These flows are dense laminar flows, but can evolve into turbidity currents by dilution of the flow and an increase in turbulence (Lowe, 1976; Mulder and Cochonat, 1996; Shanmugam, 2002). These flows form homogenous massive deposits, where the lack of fine-grained sediment constitutes a striking characteristic (Stow and Johansson, 2000). Mud clasts are frequently observed in granular flows (Lowe, 1976; Stow and Johansson, 2000 ), and their presence is often related to erosion of valley floors or flanks (Kenyon et al., 2002; Butler and Tavarnelli, 2006).

The slightly reverse to normal grading observed in core KF10 is also a characteristic of granular flows. The reverse grading in granular flow is related to an increase of the speed of the flow from the base to the top, combined with a high intergranular dispersive pressure that tends to move bigger particules from the base to the top (Lowe, 1982; Postma, 1986; Legros, 2002). The migration to the top of mud clasts ripped off the floor is interpreted as evidence for dispersive pressure (Legros, 2002). Granular flows commonly result from slopes instability. They have a limited transport capacity (Lowe, 1976; Iverson and Vallance, 2001; Legros, 2002), thus resulting deposits are usually found not far from the source.

In conclusion, based on the different criteria developed in this part, we suggest that the sedimentary sequences observed in cores KF10, KF14, KERO-05 and KERO-06 resulted from local granular flow events. These events are related to small scale landslides whose sources have not been identified yet.

\subsubsection{Highly turbulent turbidity current}

Cores KF02 and 09 show normally graded and well sorted sedimentary units. The lack of fine-grained sediment suggests that either the source was originally poor in fine sediments, or a rapid separation between fine and coarse sediments occurred in an early stage of the flow. The sediment clearly shows fluvial characteristics (Figure 8, see paragraph 4.3 for description), suggesting that they originated from the Osmondes paleo river. The river valley being entirely filled, no information about its dynamics is available. Nevertheless, considering the size of the river and the geological setting, the river probably only fed the proximal slopes. The sediment observed in the two cores is most likely related to slopes instabilities.

In the submarine environment, sediment sorting is related to flow turbulence. Turbulence increases mixing between ambient water and sediment and sorting of sediment is occurring by maintaining the less dense particles in suspension longer than the denser 
ones (Fisher, 1971; Postma, 1986). The size of the pebbles and the good sorting of the sedimentary sequence observed in core KF02 suggest that this deposit is related to fully turbulent turbidity currents, similar to what was described by Postma et al. (1988). The same conclusion is made for the sequences observed in core KF09.

By analogy with the model published by Postma et al. (1988), the sedimentary unit observed in core KF02 would correspond to deposits released by the head of the turbulent flow. In this part of the flow, sediment mixing is particularly efficient, with pebbles suspended by a strong turbulent lift (Postma et al., 1988).

\subsubsection{High-density current vs low-density current}

Cores KF03, KF04, KF05 and KF07 show more classic turbidite deposits. Core KF07, close to the shore, shows $\mathrm{Tb}, \mathrm{Td}$ and Te succession of the Bouma sequence, with two Ta units towards the top of the core. Tb and Te facies are related to classic density flows or low-density turbidity currents (Bouma, 1962; Walker, 1967; Shanmugam, 2000). Ta and $\mathrm{Tb}$ facies are related to traction transport/deposition processes, whereas $\mathrm{Td}$ and $\mathrm{Te}$ are related to transport by suspension (Bouma, 1962; Lowe, 1982). The rhythmic succession of $\mathrm{Tb}, \mathrm{Td}$ and $\mathrm{Te}$ units suggests that low-density turbidity currents occur frequently along the NE Rift Zone. These types of facies are usually associated with distal turbidite lobes (Walker, 1967; Shanmugam, 2000; Kenyon et al., 2002). This suggests that the apron near the NE Rift Zone is an area of deposition. The presence of plant fragments suggests a significant terrigenous input to the sedimentation, probably through the numerous gullies observed in the area. Core KF05 also shows rhythmic succession of $\mathrm{Td}$ and Te sequences. This rhythmic succession is interrupted by a Ta unit at $0.24 \mathrm{~m}$ that shows a well-defined erosion structure (Figure 9).

Cores KF03 and KF04 do not show rhythmic sequences as described for the two previous cores. KF03 show evidence of debris flows, highlighting the existence of highdensity flows on the distal part of the Piton de la Fournaise apron. Core KF04 shows a thick mass-transport deposit (Figure 8). The sediment characteristic of the deposit and its location suggest that the mass-transport deposit corresponds to the distal part of a debris avalanche deposit. Similar facies have been described in the Canaries Islands (Masson et al., 1997; Wynn et al., 2002c) and, more generally, large mass-transport deposits are often related to major instabilities (Masson et al., 2006; Talling et al., 2007; Lee et al., 2008).

Core KF04 shows two well-structured and normally graded turbidites (Figure 9). The Ta to Tc units are linked to traction processes. The presence of mud clasts (Figure 9) suggests a laminar flow at the base (Lowe, 1976; Lowe, 1982; Postma et al., 1983; Postma, 1986). The characteristics of these two sequences suggest that they are related to highly turbulent turbidity currents. The undulating topography across which they flowed induces rapid changes in the hydraulic behavior of the flows.

\subsubsection{Origin of gravity flows and role of volcanic activity}

The submarine flank of the Piton de la Fournaise volcano shows a significant sedimentary environment mostly dominated by slope failures of different magnitudes. Cochonat et al. (1990) already noticed that, in the absence of fluvial systems, intense 
coastal erosion would be the main source of subaerial volcaniclastic sediment. Data show that failures not only occur along the coast but also in deep water. Landslide scars observed along the valley flanks and the slumps on the valley floors (Figure 5) suggest that slope instabilities largely shaped the submarine slopes of this part of the volcano. Distal facies show evidence for large-scale debris avalanche deposits and similar high amplitude events, as proposed by Oehler et al. (2008).

Proximal areas as well as some valley floors show that some sedimentary processes are recent. This sedimentary dynamic depends directly on the volcanic activity of the Piton de la Fournaise volcano. Recurrent incursion of lava flows into the sea causes a frequent input of volcanic material. Volcaniclastic sediments are thus produced either by fragmentation of the lava flow by contact with ambient water, or by recurrent failures occurring on the newly formed lava platform (Figure 10). Depending on the magnitude of the eruption, volcaniclastic material will either deposit along the shore or in deeper water. Coastal deposits are reworked through recurrent coastal landslides or storm waves and surges, which are frequent in this part of the Indian Ocean. Other large-scale landslides and platform failures form the main feeding process to deep water. These platforms are highly unstable and their lifetime is remarkably short. For example, the platforms built after 1986 and 2004 eruptions have already disappeared (Figure 10).

Published papers on the subject consider two alternatives (Mattox and Mangan, 1997; Lee, 2005). The platform may fail entirely shortly after being built, or the platform can be dismantled by retrogressive failure over a longer period of time (Tribble, 1991; Mattox and Mangan, 1997; Lee, 2005; Sansone and Smith, 2006). The impact on deep-water sedimentation will thus depend on the type of failure. A large failure of the platform is more likely to generate a significant turbidity current reaching the abyssal plain, whereas small retrogressive failures will mostly feed the proximal area. These different types of processes explain why the proximal part of the Piton de la Fournaise slope apron shows a dynamic sedimentary system in the absence of a well-defined onshore river network.

\subsection{Facies model for volcaniclastic sedimentation in an active hotspot context}

The distribution of sedimentary facies and hemipelagic sediments suggest that most of the modern transport and deposition processes are occurring in the proximal area of the Piton de la Fournaise submarine slopes. The most active areas are the Chenal Vincent and the Plateau Sous-Marin Est, where the lack of hemipelagic sediment suggests the presence of deep-water currents that prevents the fine sediment from accumulating. For the Rale-Pousse and the distal area, the continuous Holocene sediment records in cores KF02, KF04, KF05 and KF09 suggest that no recent major events occurred on this part of the volcaniclastic apron.

Volcaniclastic sedimentation on the slopes of the Piton de la Fournaise volcano depends firstly on volcano-tectonic activity. Recurrent large-scale flank collapses affecting the volcano are the main provider of sediments to the basin (Oehler et al., 2008). These failures partly or entirely reshape the morphology of the volcano and can move a significant amount of clastic materials (several hundreds of $\mathrm{km}^{3}$ ) hundreds of kilometers from the source. This massive instantaneous input impacts deep-water sedimentation and can entirely reorganize submarine valley and channel networks. Phases of building and rebuilding also actively contribute to deep-water sedimentation processes (Figure 11). In such cases, sediment inputs are related to volcanic eruptions through failure of 
coastal lava platforms or propagation of lava flows into deep water. Nevertheless, few massive deep-water lava flows are observed on this part of the volcano. Two complementary hypotheses are proposed: (1) the lava flows were not preserved due to recurrent slope failures; and (2) the occurrence and location of these massive lava flows are related to major volcanic eruptions located close to the shore, whose recurrence is quite rare in the history of the volcano.

Even though Piton de la Fournaise is a basaltic shield volcano, ash layers related to explosive phases were identified in distal cores (Fretzdorff et al., 2000). These ash layers are rare, but are still part of the various processes recorded on the volcaniclastic apron of the volcano.

The modern eastern part of the volcano does not show any major rivers network. Small gullies do exist and constitute episodic sediment sources during flash flood events. However, the existence of the Osmondes paleoriver suggests that volcaniclastic input related to well-developed rivers might have been more important in the history of the volcano.

The volcaniclastic slope apron is also affected by autochthonous processes such as local submarine instabilities of various amplitudes (Figure 11). A clear distinction can be made between what Oehler et al. (2008) called "secondary" instabilities and minor instabilities newly described. "Secondary" instabilities are submarine large-scale failures affecting already deposited debris avalanches (Oehler et al., 2008). These "secondary" deposits occurred episodically, but they have a significant impact on the morphology of the slope apron. It has been proposed that the Vallée des Gorgones, Dépression Nord and Pente Citron Galet resulted from these types of event (Oehler et al., 2008). Minor instabilities also derive from debris avalanche deposits, but their impact on the morphology of the slopes is observed on a long-term time scale. However, their ubiquity and recurrence induces a sustained sedimentary dynamic, even if their instantaneous volume is several orders of magnitude lower than the "secondary" instabilities.

The combination of the data and different observations led to the following ideal sedimentological succession for this type of volcano-tectonic context (Figure 11): (1) during growth and rebuilding stages, sedimentary activity is mainly restricted to proximal and mid submarine slope areas. The input of sediment is low but sustained. Reccurent volcanic activity prevents hydrographic networks from developing, but active erosion is occurring on the slope apron; (2) from a certain threshold, the volcano collapses and generates massive debris avalanche deposits. These events entirely reshape the morphology of the slope apron and form massive deep water sedimentary bodies, characterized by thick sand beds in the distal part; (3) when volcanic activity slows down, erosion increases and gullies evolve into rivers bringing fluvial sediments to deep water through river delta collapse and/or hyperpycnal flows (Saint-Ange et al., 2011; Sisavath et al., 2011; Sisavath et al., 2012). This may concern the entire volcanic massif, or a part of the volcano kept out of the lava flows after a caldera collapse (see Merle et al., 2010).

This last point is well illustrated by the recently discovered Cilaos deep-sea fan on the slope apron of Piton des Neiges volcano (Saint-Ange, 2009; Saint-Ange et al., 2011; Sisavath et al., 2011). The Cilaos deep-sea fan is a well-developed volcaniclastic sandy fan, directly connected to a small drainage basin (Saint-Ange et al., 2011). Even though the stratigraphy and architecture of the fan is still puzzling, published data show that the deep-sea fan had different stages of activity and non-activity, directly related to the 
switch between periods of erosion and eruptive phases (Saint-Ange, 2009; Sisavath et al., 2011). The Cilaos deep-sea fan, attached to the old Piton des Neiges volcano, contrasts with the sedimentary systems on Piton de la Fournaise slope apron presented in this paper. It highlights the fact that in absence of well developed surficial hydrographic networks no deep-sea fan can develop, at least in this context.

Our facies model is very specific to active hot spot volcanoes. Although island arc volcanoes also experience large scale flank failures (Deplus et al., 2001; Romagnoli et al., 2009) and show a wide range of sedimentary processes (Picard et al., 2006; Casalbore et al., 2010), our facies model would require some adjustments before being applied to other settings. Indeed, the stratigraphic successions defined for Piton de La Fournaise are related to distinct volcano-tectonic stages that are also observed for other hot spot volcanoes (Moore et al., 1989; Mattox and Mangan, 1997; Schmincke and Sumita,1998; Garcia et al., 2006). The same cyclic succession would not necessarily be found in island arc setting because (1) of the tectonic setting and (2) because the type of volcanism and the nature of volcanic products play a significant role in the shape, stability and erodability of the volcano. These differences are particularly striking when comparing with Stromboli volcano where the slope apron is essentially composed of fine to coarse-grained non-consolidated materials (Casalbore et al., 2010).

\section{Conclusion}

The study of Piton de la Fournaise submarine slope apron at different scales and resolutions allowed us to describe a highly active volcaniclastic sedimentary system. This system is characterized by the presence of coarse-grained sediment waves in the proximal area, current ripples, and furrows and scours on the valley floors. A wide range of gravity flows have been identified: rocky gravity flows in the coastal area and the upper slope, granular flow from coastal to mid-slope, and highly-turbulent turbidity currents recorded in the distal area. This sedimentary dynamic, and the variety of gravity flows, is due to recurrent coastal instabilities as well as wide spread submarine instabilities from valley flanks. All these processes do not appear to be related to debris avalanche deposits, but instead shape the morphology of the volcaniclastic slope apron. These processes take place at a time when the volcano builds up, thus before and after a major flank collapse-generating debris avalanches. Based on this pattern we proposed a typical facies model for volcaniclastic succession in this setting, characterized by a cyclic succession of stages: (1) a growth stage during which sedimentary activity is restricted to proximal and mid-slope areas, (2) a collapse stage generating massive debris avalanche deposits that reshape entirely the morphology of the submarine slopes and form massive deep water sedimentary bodies, and (3) an erosional stage related to a slow down of volcanic activity. Our data show that in this volcanic setting, deep-water sedimentation processes and the type of sedimentation are strongly controlled by the morpho-tectonic evolution of the subaerial part of the volcano.

\section{Acknowledgements}

We thank the captains and crews of R/V L'Atalante and R/V Beautemps-Beaupré for their excellent work during cruises FOREVER and ERODER1, respectively. The technical and financial support of IFREMER, SHOM, Region Reunion and CNRS-INSU 
is also gratefully acknowledged. An early draft of the manuscript was significantly improved based on internal review by D.J.W. Piper, and M. Li. We are very grateful to $\mathrm{Dr}$ Daniele Casalbore and Dr Vern Manville for their constructive reviews. This is NRCan contribution $n^{\circ} 20120171$, laboratory of excellence ClerVolc contribution $n^{\circ} 52$, Ifremer "Sedimentary Systems" project (PJ2207).

\section{References}

Allen, S.R., Hayward, B.W., Mathews, E., 2007. A facies model for a submarine volcaniclastic apron: The Miocene Manukau Subgroup, New Zealand. Geological Society of America Bulletin 119, 725-742.

Arzola, R.G., Wynn, R.B., Lastras, G., Masson, D.G., Weaver, P.P.E., 2008. Sedimentary features and processes in the Nazaré and Setúbal submarine canyons, west Iberian margin. Marine Geology 250, 64-88.

Ashley, G.M., Southard, J.B., Boothroyd, J.C., 1982. Deposition of climbing-ripple beds: a flume simulation. Sedimentology 29, 67-79.

Bachèlery, P., 1981. Le Piton de la Fournaise (Ile de la Reunion). Etude volcanologique, structurale et petrologique. Piton de la Fournaise, Reunion; volcanologic, structural and petrographic study. Doctoral Thesis, Univ. of Clermont-Ferrand, Clermont-Ferrand, 255 p.

Bachèlery, P., Labazuy, P., Lénat, J.F., 1996. Submarine and subaerial debris avalanches deposits in Reunion island. Comptes Rendus de l'Académie des Sciences Series IIA - Earth and Planetary Science 323, 475-482.

Bachèlery, P. and Michon, L., 2010. The Enclos caldera: how did it form?, IAVCEI Third Workshop on Collapse Calderas, La Réunion, pp. 105-108.

Bachèlery, P., Saint-Ange, F., Villeneuve, N., Savoye, B., Normand, A., Le Drezen, E., Barrère, A., Quod, J.-P., Deplus, C., 2010. Huge lava flows into the sea and caldera collapse, April 2007, Piton de la Fournaise volcano, IAVCEI Third Workshop on Collapse Calderas, La Réunion, pp. 73-74.

Blair, T.C., McPherson, J.G., 1999. Grain-size and textural classification of coarse sedimentary particles. Journal of Sedimentary Research 69, 6-19.

Bonneville A., Barriot J.P., Bayer R., 1988. Evidence from geoid data of a hot spot origin for the southern Mascarene Plateau and Mascarene Islands (Indian Ocean), J. Geophys. Res. 93, 4199-4211.

Bouma, A.H., 1962. Sedimentology of some flysch deposits: a graphic approach to facies interpretation. Amsterdam, Elsevier.

Busby, C.J., 1988. Evolution of a Middle Jurassic back-arc basin, Cedros Island, Baja California: Evidence from a marine volcaniclastic apron. Geological Society of America Bulletin 100, 218-233. 
Butler, R.W.H., Tavarnelli, E., 2006. The structure and kinematics of substrate entrainment into high-concentration sandy turbidites: a field example from the Gorgoglione 'flysch' of southern Italy. Sedimentology 53, 655-670.

Canals, M., Lastras, G., Urgeles, R., Casamor, J.L., Mienert, J., Cattaneo, A., De Batist, M., Haflidason, H., Imbo, Y., Laberg, J.S., Locat, J., Long, D., Longva, O., Masson, D.G., Sultan, N., Trincardi, F., Bryn, P., 2004. Slope failure dynamics and impacts from seafloor and shallow sub-seafloor geophysical data: case studies from the COSTA project. Marine Geology 213, 9-72.

Carey, S.N., Schneider JL., Volcaniclastic Processes and Deposits in the Deep-Sea. In Heiko $n$ eke and Thierry ulder editors evelopments in edimentology Vol.

Amsterdam: The Netherlands, 2011, pp. 457-515.

Cartigny, M.J.B., Postma, G., van den Berg, J.H., Mastbergen, D.R., 2011. A comparative study of sediment waves and cyclic steps based on geometries, internal structures and numerical modeling. Marine Geology 280, 40-56.

Casalbore, D., Romagnoli, C., Chiocci, F. and Frezza, V., 2010. Morpho-sedimentary characteristics of the volcaniclastic apron around Stromboli volcano (Italy). Marine Geology 269, 132-148.

Cochonat, P., Lenat, J.F., Bachèlery, P., Boivin, P., Cornaglia, B., Deniel, C., Labazuy, P., Ledrezen, E., Lipman, P., Ollier, G., Savoye, B., Vincent, P., Voisset, M., 1990. Gravity Events as a Primary Process in the Construction of a Submarine VolcanoSedimentary System (Fournaise Volcano, Reunion-Island). Comptes Rendus De L'Academie Des Sciences Serie II 311, 679-686.

Courteaud, M., 1996. Etude des structures géologiques et hydrogéologiques du massif de La Fournaise par la méthode audio magnétotellurique, PhD Thesis, Université de La Réunion, p. 212.

Crandell, D. R., and Fahnestock, R. K., 1965. Rockfalls and avalanches from Little Tahoma Peak on Mount Rainier, Washington, U. S. Geological Survey Bulletin 1221 - A, $30 \mathrm{p}$.

Deplus, C. et al., 2001. Submarine evidence for large-scale debris avalanches in the Lesser Antilles Arc. Earth and Planetary Science Letters 192, 145-157.

Duffield, W.A., Stieltjes, L., Varet, J., 1982. Huge landslide blocks in the growth of Piton de la Fournaise, La Réunion, and Kilauea volcano, Hawaii. Journal of Volcanology and Geothermal Research 12, 147-160.

Duncan, R.A., 1990. The volcanic record of the Réunion hotspot. In Duncan, R.A., Backman, J., Peterson, L.C., et al., Proc. ODP, Sci. Results, 115: College Station, TX (Ocean Drilling Program), 3-10. doi:10.2973/odp.proc.sr.115.206.1990.

Fisher, R.V., 1961. Proposed classification of volcaniclastic sediments and rocks. Geological Society of America Bulletin 72, 1409-1414. 
Fisher, R.V., 1971. Features of coarse-grained, high-concentration fluids and their deposits. Journal of Sedimentary Research 41, 916-927.

Flood, R.D., 1983. Classification of sedimentary furrows and a model for furrow initiation and evolution. Geological Society of America Bulletin 94, 630-639.

Fretzdorff, S., Paterne, M., Stoffers, P., Ivanova, E., 2000. Explosive activity of the Reunion Island volcanoes through the past 260,000 years as recorded in deep-sea sediments. Bulletin of Volcanology 62, 266-277.

Gailler, L.-S., Lénat, J.-F., 2010. Three-dimensional structure of the submarine flanks of La Réunion inferred from geophysical data. Journal of Geophysical Research 115, B12105.

Garcia, M.O. et al., 2006. Frequent landslides from Koolau Volcano: Results from ODP Hole 1223A. Journal of Volcanology and Geothermal Research 151, 251-268.

Habgood, E.L., Kenyon, N.H., Masson, D.G., Akhmetzhanov, A., Weaver, P.P.E., Gardner, J., Mulder, T., 2003. Deep-water sediment wave fields, bottom current sand channels and gravity flow channel-lobe systems: Gulf of Cadiz, NE Atlantic. Sedimentology 50, 483-510.

Hersen, P., 2005. Flow effects on the morphology and dynamics of aeolian and subaqueous barchan dunes. Journal of Geophysical Research 110, F04S07, doi:10.1029/2004JF000185.

Hughes Clarke, J.E., Shor, A.N., Piper, D.J.W., Mayer, L.A., 1990. Large-scale currentinduced erosion and deposition in the path of the 1929 Grand Banks turbidity current. Sedimentology 37, 613-629.

Iverson, R.M., Vallance, J.W., 2001. New views of granular mass flows. Geology 29, 115-118.

Jerolmack, D.J., Mohrig, D., 2005. A unified model for subaqueous bed form dynamics. Water Resources Research 41, W12421, doi:10.1029/2005WR004329.

Kenyon, N.H., Belderson, R.H., 1973. Bed forms of the Mediterranean undercurrent observed with side-scan sonar. Sedimentary Geology 9, 77-99.

Kenyon, N.H., Klaucke, I., Millington, J., Ivanov, M.K., 2002. Sandy submarine canyonmouth lobes on the western margin of Corsica and Sardinia, Mediterranean Sea. Marine Geology 184, 69-84.

Kidd, R.B., Lucchi, R.G., Gee, M., Woodside, J.M., 1998. Sedimentary processes in the Stromboli Canyon and Marsili Basin, SE Tyrrhenian Sea: results from side-scan sonar surveys. Geo-Marine Letters 18, 146-154.

Kieffer, G., 1990. Grand traits morphologiques de l'île de la Réunion (Océan Indien). In: J.F. Lénat (Ed.), Le Volcanisme de la Réunion - Monographie, pp. 75-114. 
Klaucke, I., Savoye, B., Cochonat, P., 2000. Patterns and processes of sediment dispersal on the continental slope off Nice, SE France. Marine Geology 162, 405-422.

Krapež, B., Hand, J.L., 2008. Late Archaean deep-marine volcaniclastic sedimentation in an arc-related basin: The Kalgoorlie Sequence of the Eastern Goldfields Superterrane, Yilgarn Craton, Western Australia. Precambrian Research 161, 89-113.

Labazuy, P., 1991. Instabilités au cours de l'évolution d'un édifice volcanique volcanique, en domaine intraplaque océanique: Le Piton de la Fournaise (Ile de La Réunion). Univ. Clermont-Fd, p. 231.

Labazuy, P., 1996. Recurrent landslides events on the submarine flank of Piton de La Fournaise volcano (Reunion Island), In: McGuire, W.J., Jones, A.P., Neuberg, J. (Eds.), Volcano Instability on the Earth and Other Planets. Geological Society Special Publication $\mathrm{N}^{\circ}$. 110, pp. 295-306.

Lee, H.J., 2005. Undersea landslides: extent and significance in the Pacific Ocean, an update. Natural Hazards and Earth System Sciences 5, 877-892.

Lee, H., Shum, C.K., Yi, Y., Braun, A., Kuo, C.-Y., 2008. Laurentia crustal motion observed using TOPEX/POSEIDON radar altimetry over land. Journal of Geodynamics $46,182-193$.

Legros, F., 2002. Can dispersive pressure cause inverse grading in grain flows? Journal of Sedimentary Research 72, 166-170.

Lénat, J.-F., Vincent, P., Bachèlery, P., 1989. The off-shore continuation of an active basaltic volcano: Piton de la Fournaise (Réunion Island, Indian Ocean); structural and geomorphological interpretation from sea beam mapping. Journal of Volcanology and Geothermal Research 36, 1-36.

Lénat, J.-F., Gibert-Malengreau, B., Galdéano, A., 2001. A new model for the evolution of the volcanic island of Réunion (Indian Ocean). Journal of Geophysical Research 106, 8645-8663.

Lénat, J.-F., Boivin, P., Deniel, C., Gillot, P.-Y., Bachèlery, P., 2009. Age and nature of deposits on the submarine flanks of Piton de la Fournaise (Reunion Island). Journal of Volcanology and Geothermal Research 184, 199-207.

Livingstone, I., Wiggs, G.F.S., Weaver, C.M., 2007. Geomorphology of desert sand dunes: A review of recent progress. Earth-Science Reviews 80, 239-257.

Lowe, D.R., 1976. Grain flow and grain flow deposits. Journal of Sedimentary Research 46, 188-199.

Lowe, D.R., 1982. Sediment gravity flows; II, Depositional models with special reference to the deposits of high-density turbidity currents. Journal of Sedimentary Research 52, 279-297. 
Mairine, P., Bachèlery, P., 1997. Un grand épisode érosionnel dans l'histoire ancienne du Piton de la Fournaise (île de la Réunion). Comptes Rendus de l'Académie des Sciences - Series IIA - Earth and Planetary Science 325, 243-249.

Mángano, M.G., Buatois, L.A., 1997. Slope-apron deposition in an Ordovician arcrelated setting: the Vuelta de Las Tolas Member (Suri Formation), Famatina Basin, northwest Argentina. Sedimentary Geology 109, 155-180.

Manville, V., Németh, K., Kano, K., 2009. Source to sink: A review of three decades of progress in the understanding of volcaniclastic processes, deposits, and hazards. Sedimentary Geology 220, 136-161.

Masson, D.G., Van Niel, B., Weaver, P.P.E., 1997. Flow processes and sediment deformation in the Canary Debris Flow on the NW African Continental Rise. Sedimentary Geology 110, 163-179.

Masson, D.G., Watts, A.B., Gee, M.J.R., Urgeles, R., Mitchell, N.C., Le Bas, T.P., Canals, M., 2002. Slope failures on the flanks of the western Canary Islands. EarthScience Reviews 57, 1-35.

Masson, D.G., Harbitz, C.B., Wynn, R.B., Pedersen, G., Løvholt, F., 2006. Submarine landslides: processes, triggers and hazard prediction. Philosophical Transactions of the Royal Society A: Mathematical, Physical and Engineering Sciences 364, 2009-2039.

Mattox, T.N., Mangan, M.T., 1997. Littoral hydrovolcanic explosions: a case study of lava-seawater interaction at Kilauea Volcano. Journal of Volcanology and Geothermal Research 75, 1-17.

Merle, O., Lénat, J.-F., 2003. Hybrid collapse mechanism at Piton de la Fournaise volcano, Reunion Island, Indian Ocean. J. Geophys. Res. 108, 2166.

Merle, O., Mairine, P., Michon, L., Bachèlery, P., Smietana, M., 2010. Calderas, landslides and paleo-canyons on Piton de la Fournaise volcano (La Réunion Island, Indian Ocean). Journal of Volcanology and Geothermal Research 189, 131-142.

Michon, L., Saint-Ange, F., 2008. Morphology of Piton de la Fournaise basaltic shield volcano (La Réunion Island): Characterization and implication in the volcano evolution Journal of Geophysical Research 113, B03203, doi:10.1029/2005JB004118.

Mitchell, N.C., Beier, C., Rosin, P.L., Quartau, R., Tempera, F., 2008. Lava penetrating water: Submarine lava flows around the coasts of Pico Island, Azores. Geochemistry Geophysics Geosystems 9, Q03024, 10.1029/2007gc001725.

Moore, J.G., Clague, D.A., Holcomb, R.T., Lipman, P.W., Normark, W.R., Torresan, M.E., 1989. Prodigious Submarine Landslides on the Hawaiian Ridge. Journal of Geophysical Research 94, 17465-17484.

Mulder, T., Cochonat, P., 1996. Classification of offshore mass movements. Journal of Sedimentary Research 66, 43-57. 
Oehler, J.-F., Labazuy, P., Lénat, J.-F., 2004. Recurrence of major flank landslides during the last 2-Ma-history of Reunion Island. Bulletin of Volcanology 66, 585-598.

Oehler, J.-F., Lénat, J.-F., Labazuy, P., 2008. Growth and collapse of the Reunion Island volcanoes. Bulletin of Volcanology 70, 717-742.

Ollier, G., Cochonat, P., Lenat, J.F., Labazuy, P., 1998. Deep-sea volcaniclastic sedimentary systems: an example from La Fournaise volcano, Réunion Island, Indian Ocean. Sedimentology 45, 293-330.

Peltier, A., Bachèlery, P., Staudacher, T., 2009. Magma transport and storage at Piton de La Fournaise (La Réunion) between 1972 and 2007: A review of geophysical and geochemical data. Journal of Volcanology and Geothermal Research 184, 93-108.

Picard, M., Schneider, J.-L. and Boudon, G., 2006. Contrasting sedimentary processes along a convergent margin: the Lesser Antilles arc system. Geo-Marine Letters 26, 397410.

Piper, D.J.W., Shor, A.N., Farre, J.A., Connell, S., Jacobi, R., 1985. Sediment slides and turbidity currents on the Laurentian Fan: Sidescan sonar investigations near the epicenter of the 1929 Grand Banks earthquake. Geology 13, 538-541.

Piper, D.J.W., Kontopoulos, N., 1994. Bed forms in submarine channels; comparison of ancient examples from Greece with studies of Recent turbidite systems. Journal of Sedimentary Research 64, 247-252.

Ponce, J.J., Carmona, N., 2011. Coarse-grained sediment waves in hyperpycnal clinoform systems, Miocene of the Austral foreland basin, Argentina. Geology 39, 763766.

Postma, G., 1986. Classification for sediment gravity-flow deposits based on flow conditions during sedimentation. Geology 14, 291-294.

Postma, G., Nemec, W. and Kleinspehn, K.L., 1988. Large floating clasts in turbidites: a mechanism for their emplacement. Sedimentary Geology 58, 47-61.

Postma, G., Roep, T.B., Ruegg, G.H.J., 1983. Sandy-gravelly mass-flow deposits in an ice-marginal lake (Saalian, Leuvenumsche Beek Valley, Veluwe, the Netherlands), with emphasis on plug-flow deposits. Sedimentary Geology 34, 59-82.

Romagnoli, C., Casalbore, D., Chiocci, F.L. and Bosman, A., 2009. Offshore evidence of large-scale lateral collapses on the eastern flank of Stromboli, Italy, due to structurallycontrolled, bilateral flank instability. Marine Geology 262, 1-13.

Saint-Ange, F., 2009. La sédimentation volcanoclastique en contexte de point chaud (île de La Réunion, Océan Indien), PhD Thesis, Université de La Réunion/IFREMER, p. 279. http://www.asf.epoc.u-bordeaux1.fr/theses/theses Prix Gubler 2011.html

Saint-Ange, F., Savoye, B., Michon, L., Bachèlery, P., Deplus, C., De Voogd, B., Dyment, J., Le Drezen, E., Voisset, M., Le Friant, A., Boudon, G., 2011. A volcaniclastic 
deep-sea fan off La Réunion Island (Indian Ocean): Gradualism versus catastrophism. Geology 39, 271-274.

Sansone, F.J., Smith, J.R., 2006. Rapid mass wasting following nearshore submarine volcanism on Kilauea volcano, Hawaii. Journal of Volcanology and Geothermal Research 151, 133-139.

Shanmugam, G., 2000. 50 years of the turbidite paradigm (1950s-1990s): deep-water processes and facies models--a critical perspective. Marine and Petroleum Geology 17, 285-342.

Shanmugam, G., 2002. Ten turbidite myths. Earth-Science Reviews 58, 311-341.

Schmincke, H.-U., Sumita, M., 1998. Volcanic evolution of Gran Canaria reconstructed from apron sediments: synthesis of VICAP project drilling, In: Weaver, P.P.E., Schmincke, H.-U., Firth, J., Duffield, W. (Eds.), Proc. ODP, Sci. Results, 157: College Station, TX (Ocean Drilling Program), pp. 443-469.

Shor, A.N., Piper, D.J.W., Hughes Clarke, J.E., Mayer, L.A., 1990. Giant flute-like scour and other erosional features formed by the 1929 Grand Banks turbidity current. Sedimentology 37, 631-645.

Sisavath, E., Babonneau, N., Saint-Ange, F., Bachèlery, P., Jorry, S.J., Deplus, C., De Voogd, B., Savoye, B., 2011. Morphology and sedimentary architecture of a modern volcaniclastic turbidite system: The Cilaos fan, offshore La Réunion Island. Marine Geology 288, 1-17.

Sisavath, E., Mazuel, A., Jorry, S.J., Babonneau, N., Bachèlery, P., de Voogd, B., Salpin, M., Emmanuel, L., Beaufort, L., and Toucanne, S. 2012. Processes controlling a volcaniclastic turbiditic system during the last climatic cycle: Example of the Cilaos deepsea fan, offshore La Réunion Island. Sedimentary Geology 281, 180-193.Smietana, M., 2011. Pétrologie, géochronologie (K-Ar) et géochimie élémentaire et isotopique $(\mathrm{Sr}, \mathrm{Nd}$,

$\mathrm{f} \mathrm{Pb}$ ) de laves anciennes de La Réunion Implications sur la construction de l'édifice volcanique, PhD Thesis, Université de La Réunion, p. 237

Staudacher, T., Ferrazzini, V., Peltier, A., Kowalski, P., Boissier, P., Catherine, P., Lauret, F., Massin, F., 2009. The April 2007 eruption and the Dolomieu crater collapse, two major events at Piton de la Fournaise (La Réunion Island, Indian Ocean). Journal of Volcanology and Geothermal Research 184, 126-137.

Stow, D.A.V., Johansson, M., 2000. Deep-water massive sands: nature, origin and hydrocarbon implications. Marine and Petroleum Geology 17, 145-174.

Talling, P.J., Amy, L.A., Wynn, R.B., 2007. New insight into the evolution of large-volume turbidity currents: comparison of turbidite shape and previous modelling results. Sedimentology 54, 737-769.

Tribble, G.W., 1991. Underwater observations of active lava flows from Kilauea volcano, Hawaii. Geology 19, 633-636. 
Todd, B.J., 2005. Morphology and composition of submarine barchan dunes on the Scotian Shelf, Canadian Atlantic margin. Geomorphology 67, 487-500.

Walker, R.G., 1967. Turbidite sedimentary structures and their relationship to proximal and distal depositional environments. Journal of Sedimentary Research 37, 25-43.

Walker, R.G., 1984. Facies Models, Walker, R.G. eds, 317p.

Walker, G.P.L., 1990. Geology and volcanology of the Hawaiian Islands. Pacific Science 44, 315-345.

Wynn, R.B., Masson, D.G., Stow, D.A.V., Weaver, P.P.E., 2000. Turbidity current sediment waves on the submarine slopes of the western Canary Islands. Marine Geology 163, 185-198.

Wynn, R.B., Masson, D.G., Bett, B.J., 2002a. Hydrodynamic significance of variable ripple morphology across deep-water barchan dunes in the Faroe-Shetland Channel. Marine Geology 192, 309-319.

Wynn, R.B., Piper, D.J.W., Gee, M.J.R., 2002b. Generation and migration of coarsegrained sediment waves in turbidity current channels and channel-lobe transition zones. Marine Geology 192, 59-78.

Wynn, R.B., Weaver, P.P.E., Masson, D.G., Stow, D.A.V., 2002c. Turbidite depositional architecture across three interconnected deep-water basins on the north-west African margin. Sedimentology 49, 669-695.

\section{Figure captions}

Figure 1: Simplified morpho-structural scheme of the submarine slopes of the Piton de la Fournaise volcano; A: shaded relief map; B: morpho-structural scheme; F.O: Formations Occidentales; PdF: Piton de la Fournaise; PdN: Piton des Neiges.

Figure 2: Data location and shaded relief map of the Piton de la Fournaise volcano and its volcaniclastic slope apron. Yellow boxes are locations of the Synthetic Aperture Radar (SAR) images shown on Figure 5.

Figure 3: Morphological connections between onshore-offshore structures. NLD: Northern Lava Delta; MLD: Median Lava Delta.

Figure 4: Proximal area of the submarine slopes of the Piton de la Fournaise (Digital Elevation Model: $25 \mathrm{~m}$ of resolution). A: shaded relief map; B: backscatter map; Letters in map - B: blocks; c: channels; Id: lava delta; R: ridge

Figure 5: Side scan data (see figure 1 for location). White arrows show flow orientation.

Figure 6: Deep-water photographs taken during FOURNAISE 2 cruise (see figure 2 for location of photos). A to D: photos 2, 1, 3 and 9; fields of sands and gravels. $E$ to $G$ : 
photos 16, 10 and 15; debris avalanche deposits outcrops; blocs and breccias are observed.

Figure 7: Deep-water photographs taken during FOURNAISE 2 cruise (see figure 2 for location). A: photo 12 taken in the Chenal Vincent showing coarse-grained ripples; $\mathrm{B}$ : photo 4 showing sandy current ripple downstream of the Chenal Vincent at the start of the Râlé-Poussé area; C and D: photos 13 and 17 showing small current ripples upstream and downstream of the Vallée des Gorgones; E: photo 8 taken upstream of the Dépression Nord showing field of coarse-grained sediments partially draped by fine grain sediment $\mathrm{F}$ : photo 5 showing hemipelagic sediments downstream of the Dépression Nord (note the Anemone on the right of the picture).

Figure 8: Log summary of FOURNAISE 2 cores (KF) and ERODER 1 cores (KERO) (see figure 2 for location); Downcore depth in m; cs: coarse silt; s: very fine sand; f: fine sand; c: coarse sand; G: gravel.

Figure 9: Grain size analysis of different turbidites sequence. Downcore depth is in $\mathrm{cm}$; S1 and S2 indicate core section 1 and 2 respectively; Turbidite sequences ( $\mathrm{Ta}-\mathrm{Te}$ ) defined after Bouma (1962); N.G.: Normal Grading; Rv.G.: Reverse Grading.

Figure 10: Succession of photos taken from 2004 to the end of 2005 showing the retreat of the newly built coast line due to recurrent failures of the lava platforms (photographs: courtesy of Aline Peltier).

Figure 11: Facies model of volcaniclastic sedimentation established for the Piton de La Fournaise volcano. D.F.: debris flow; H: hemipelagic sediment; T.L: silt-sand turbidite laminae; T.S: turbidite sequence; Arrows indicate flow direction. 

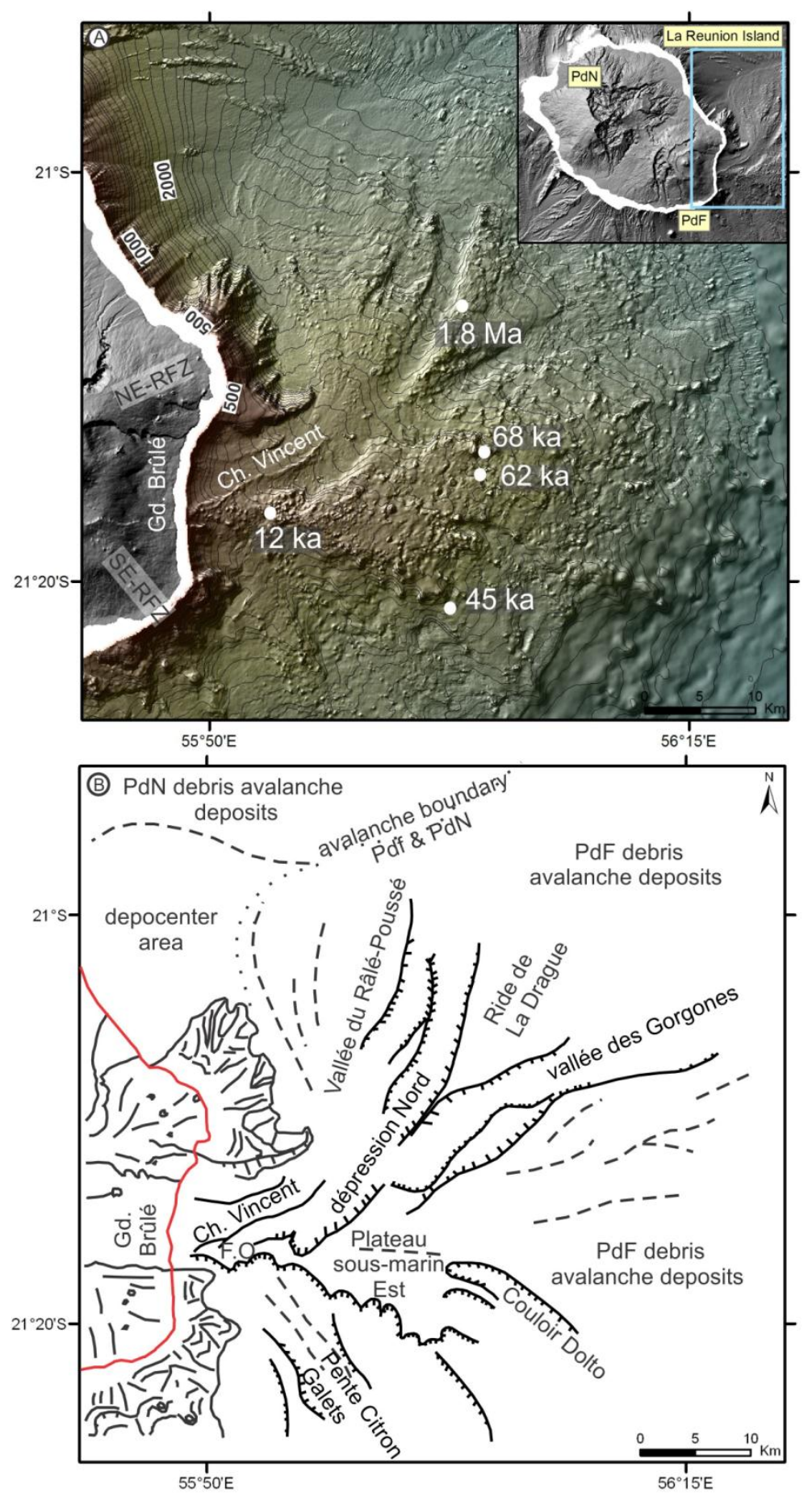

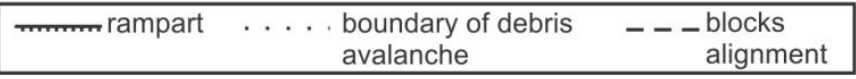




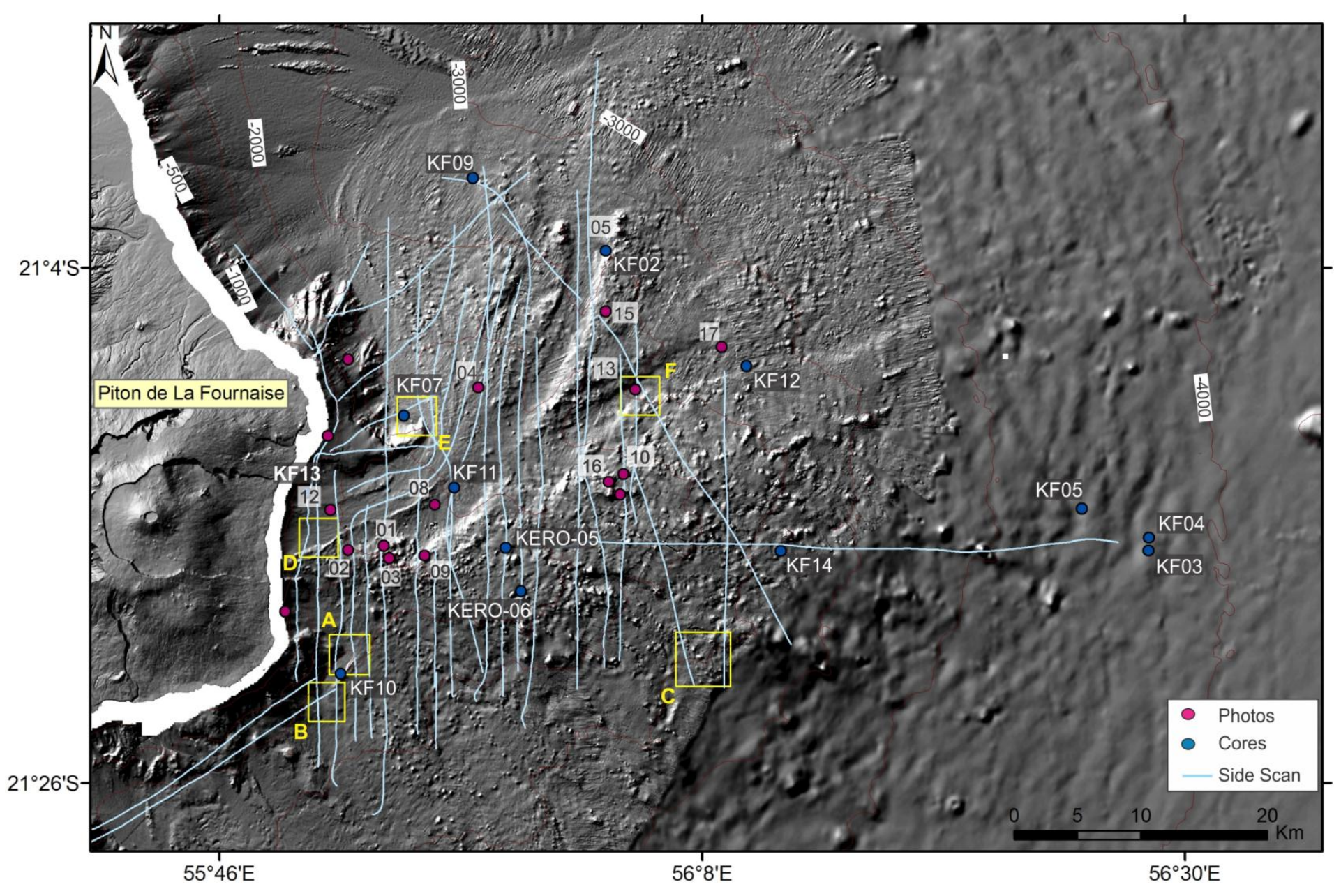



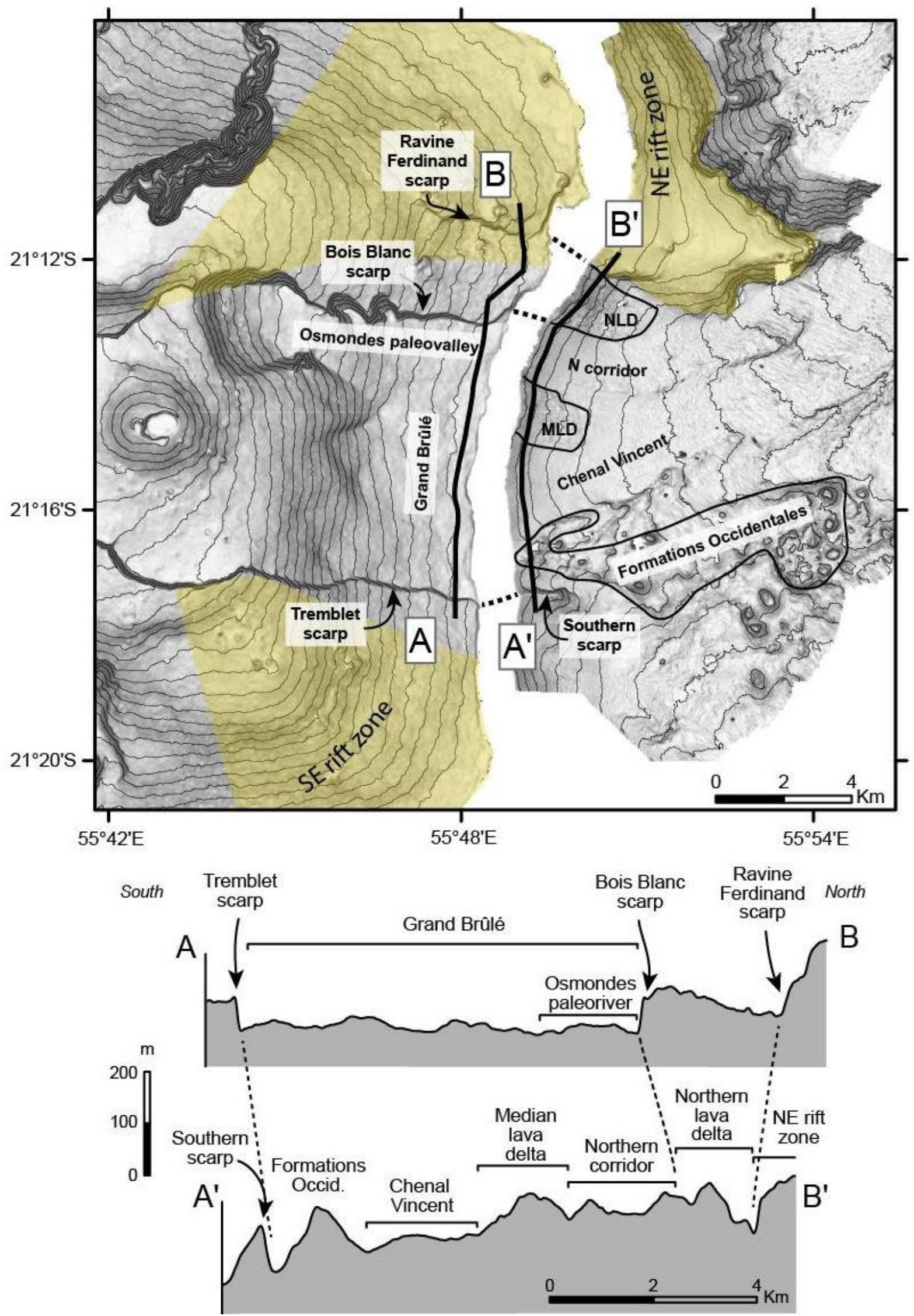
Figure 4

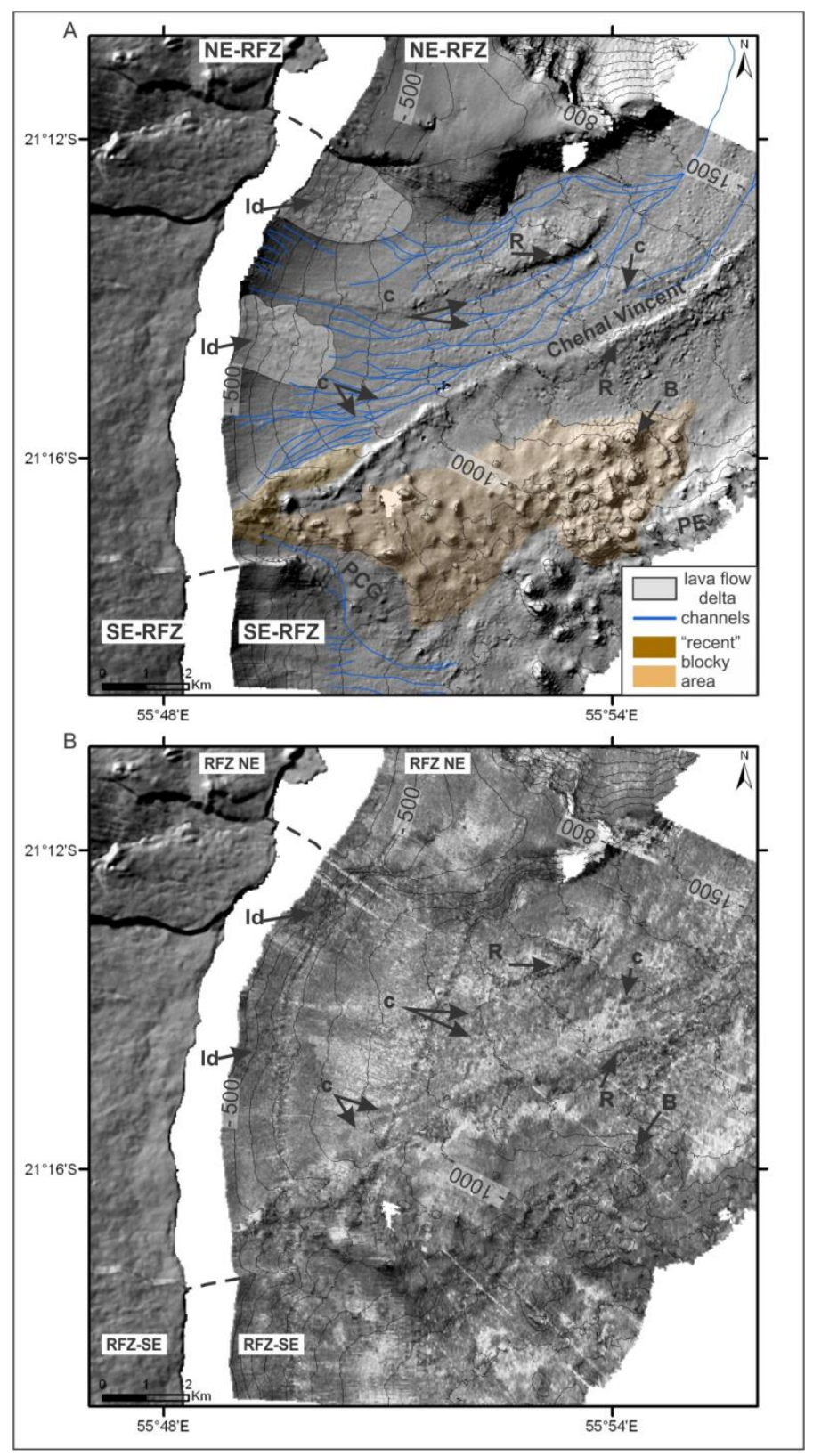




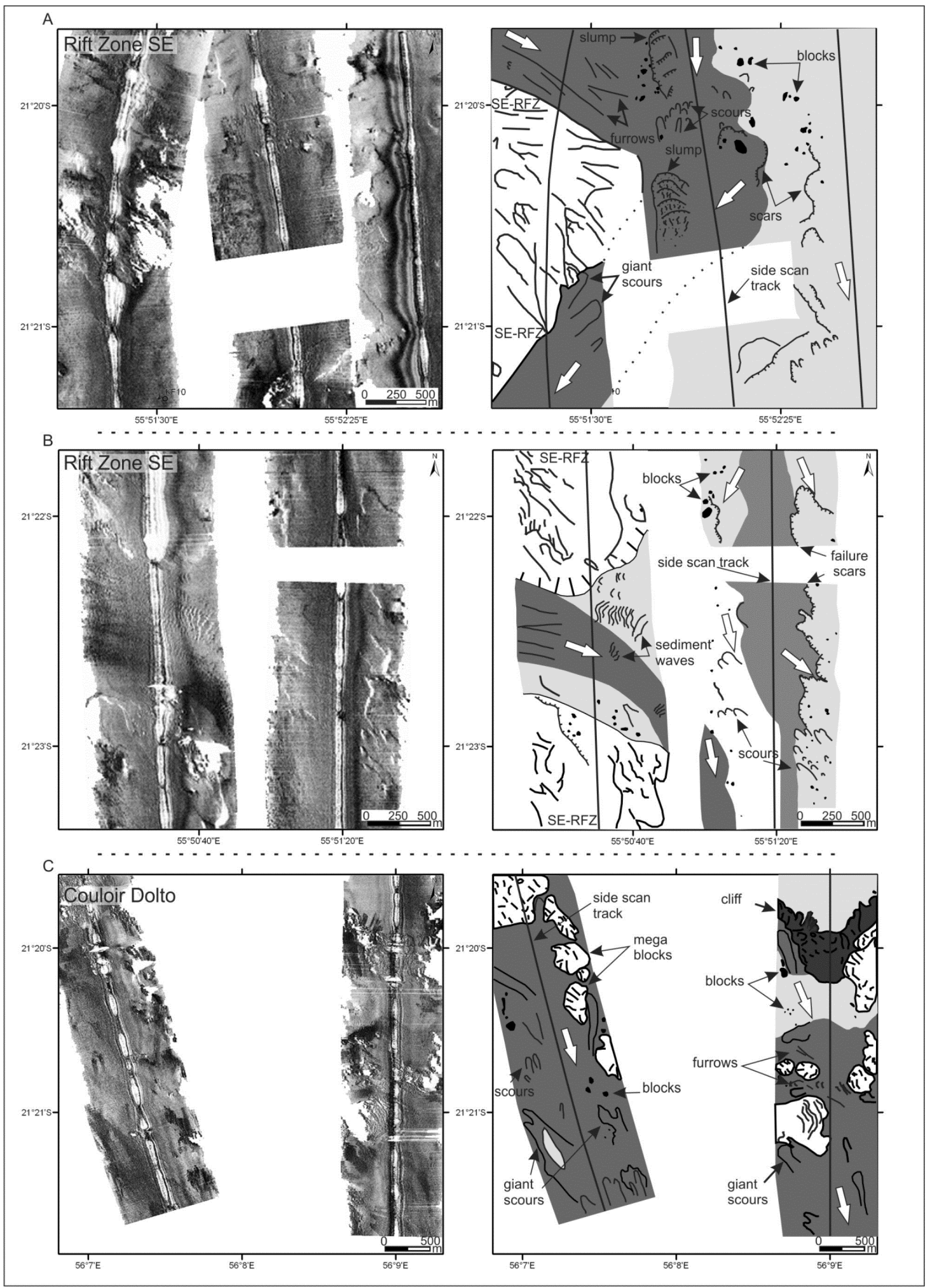




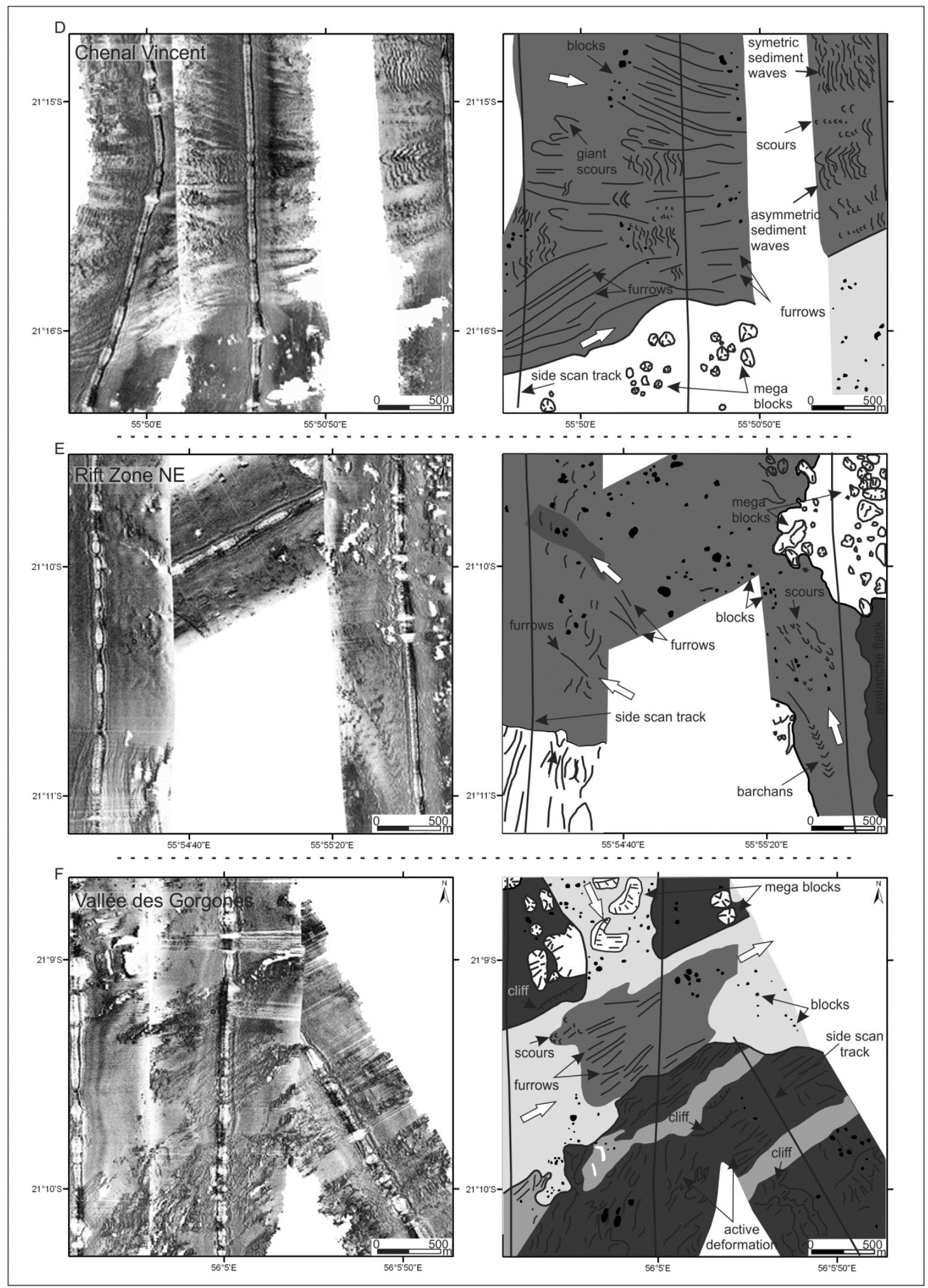



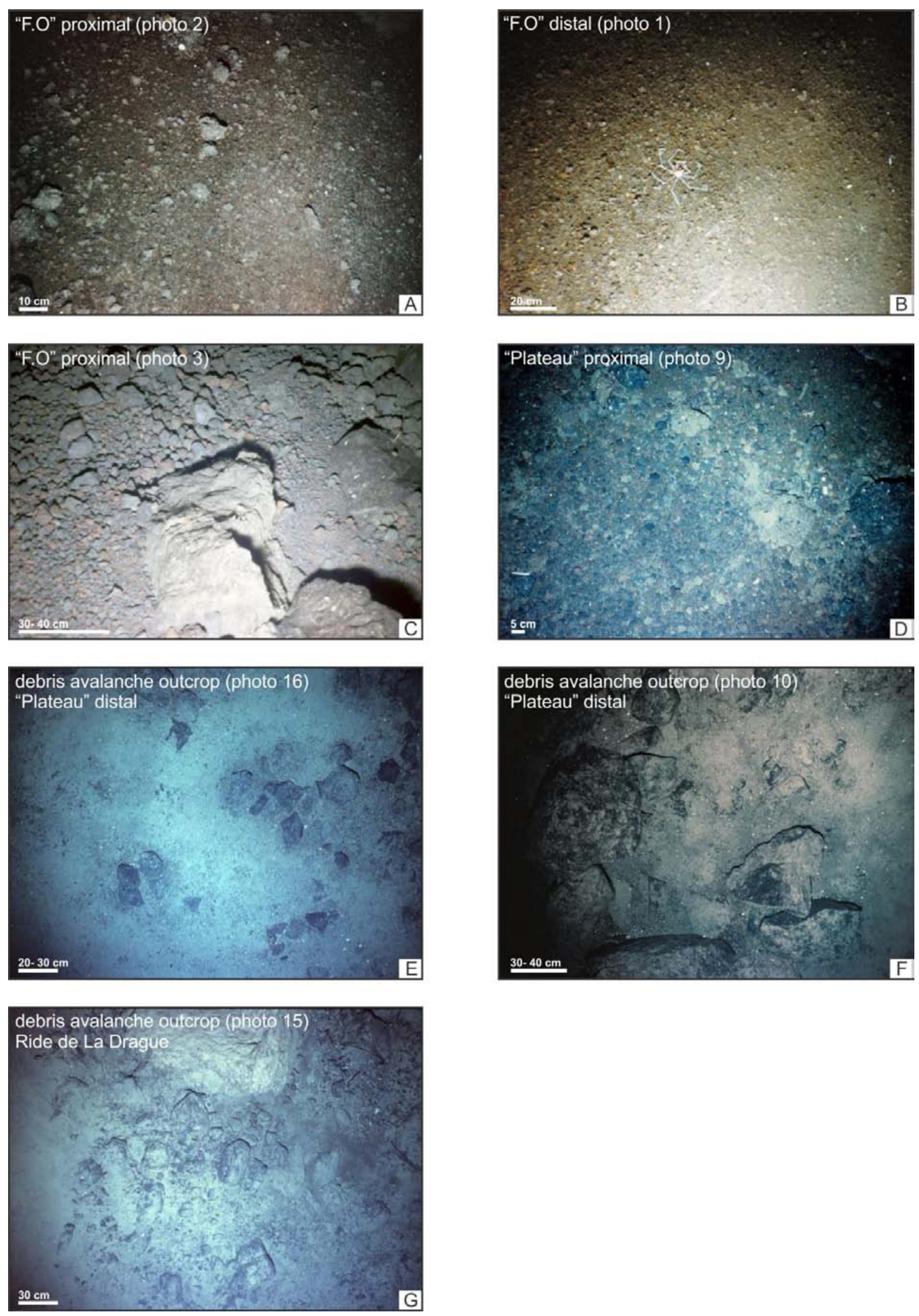

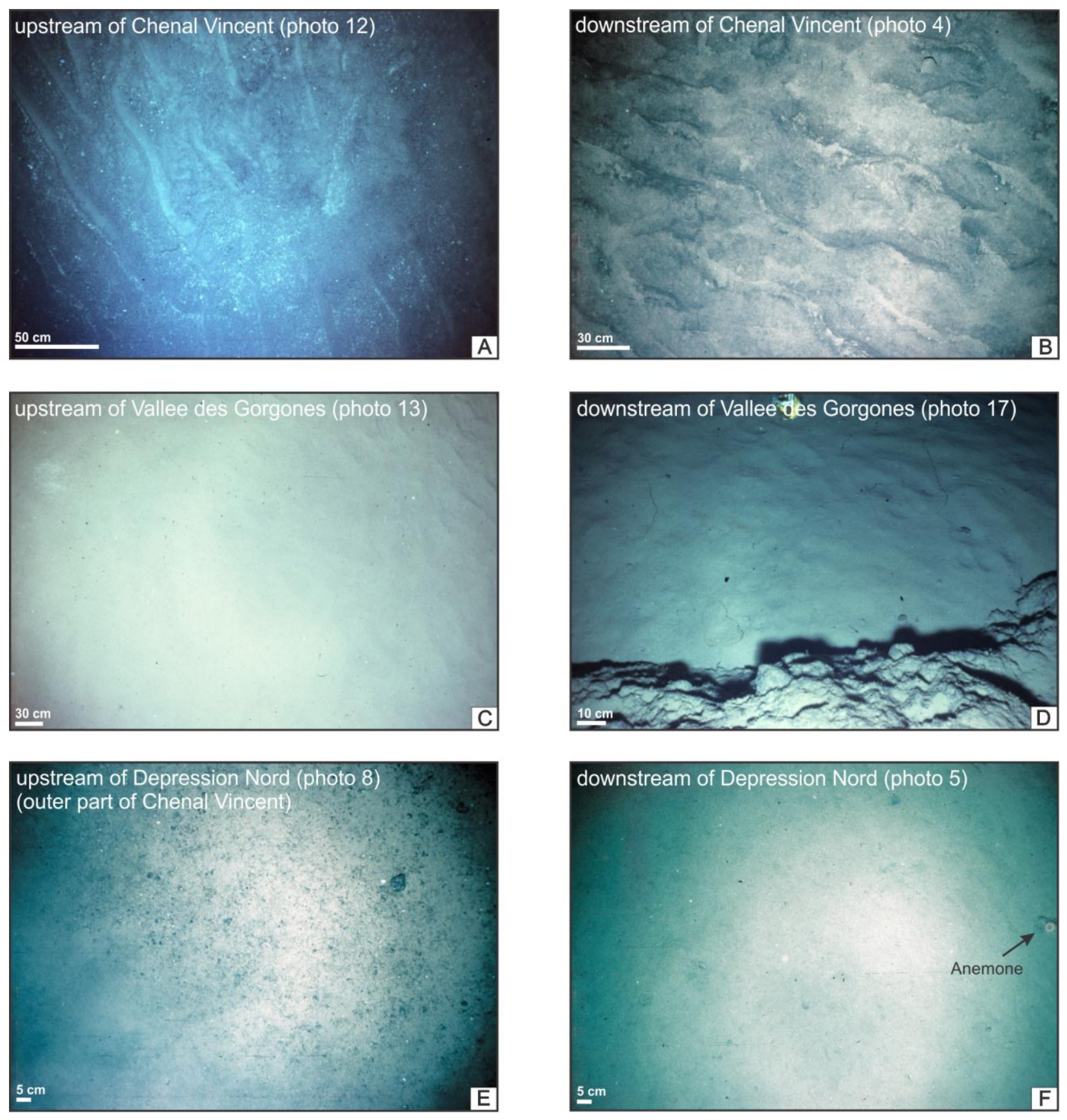
Figure 8

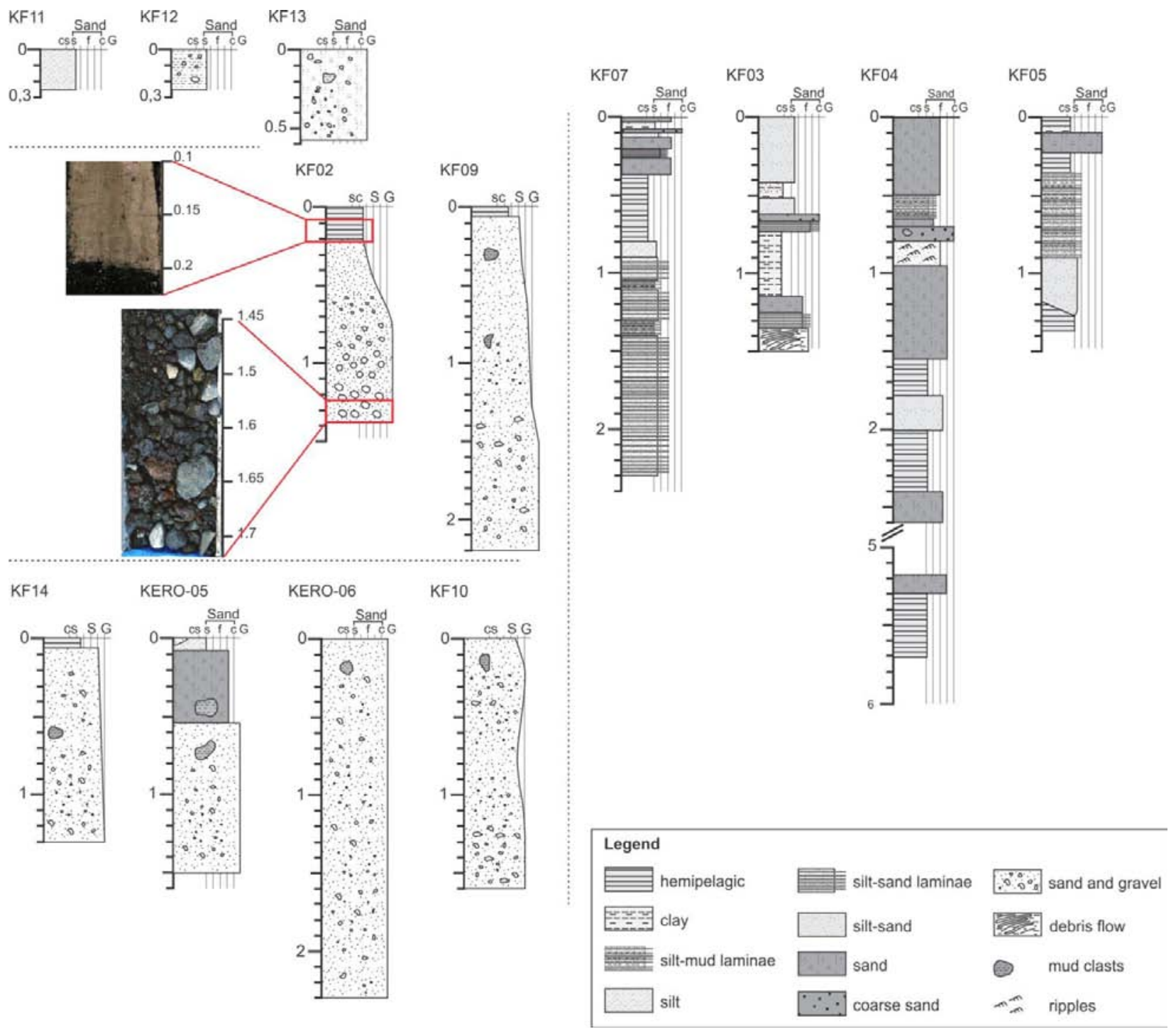



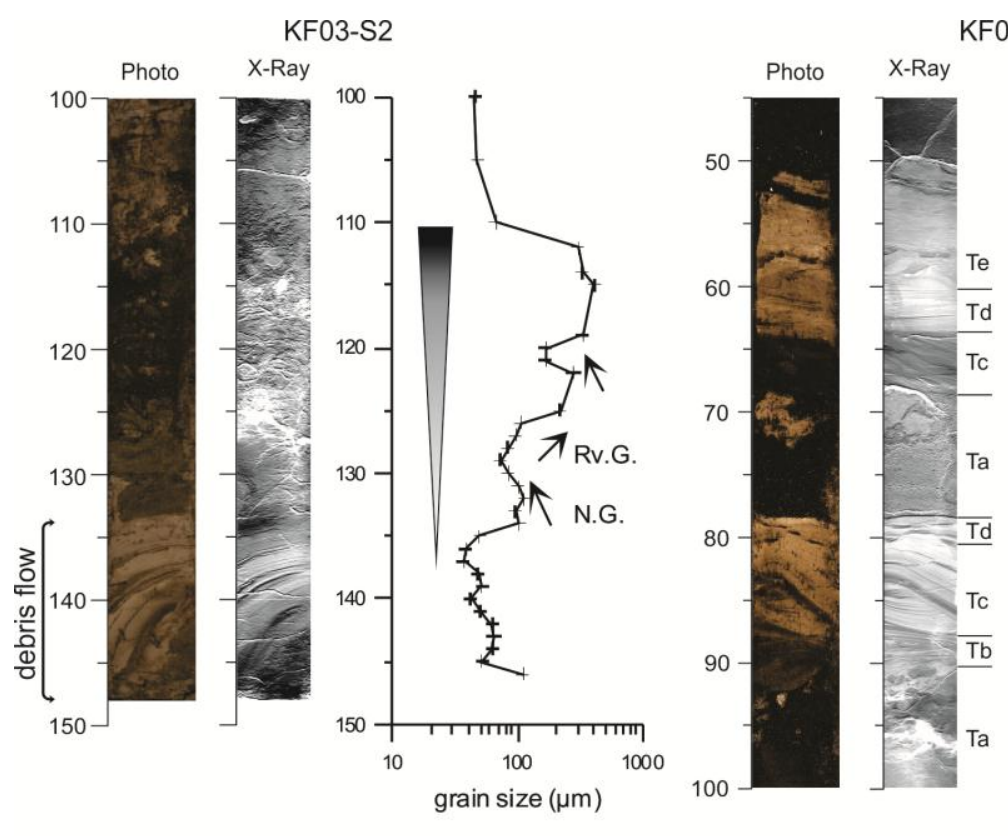

KF04-S2
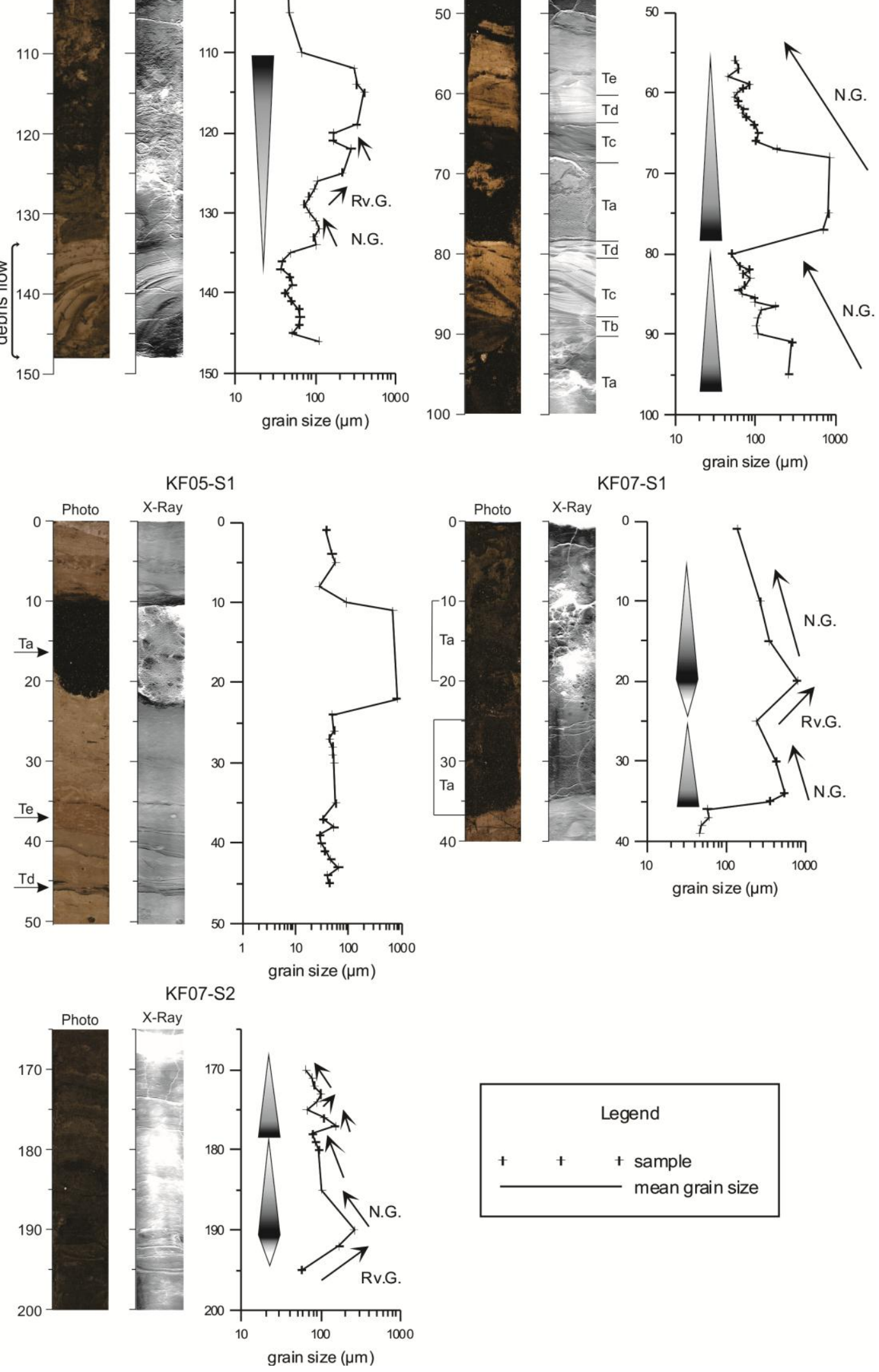
Figure 10

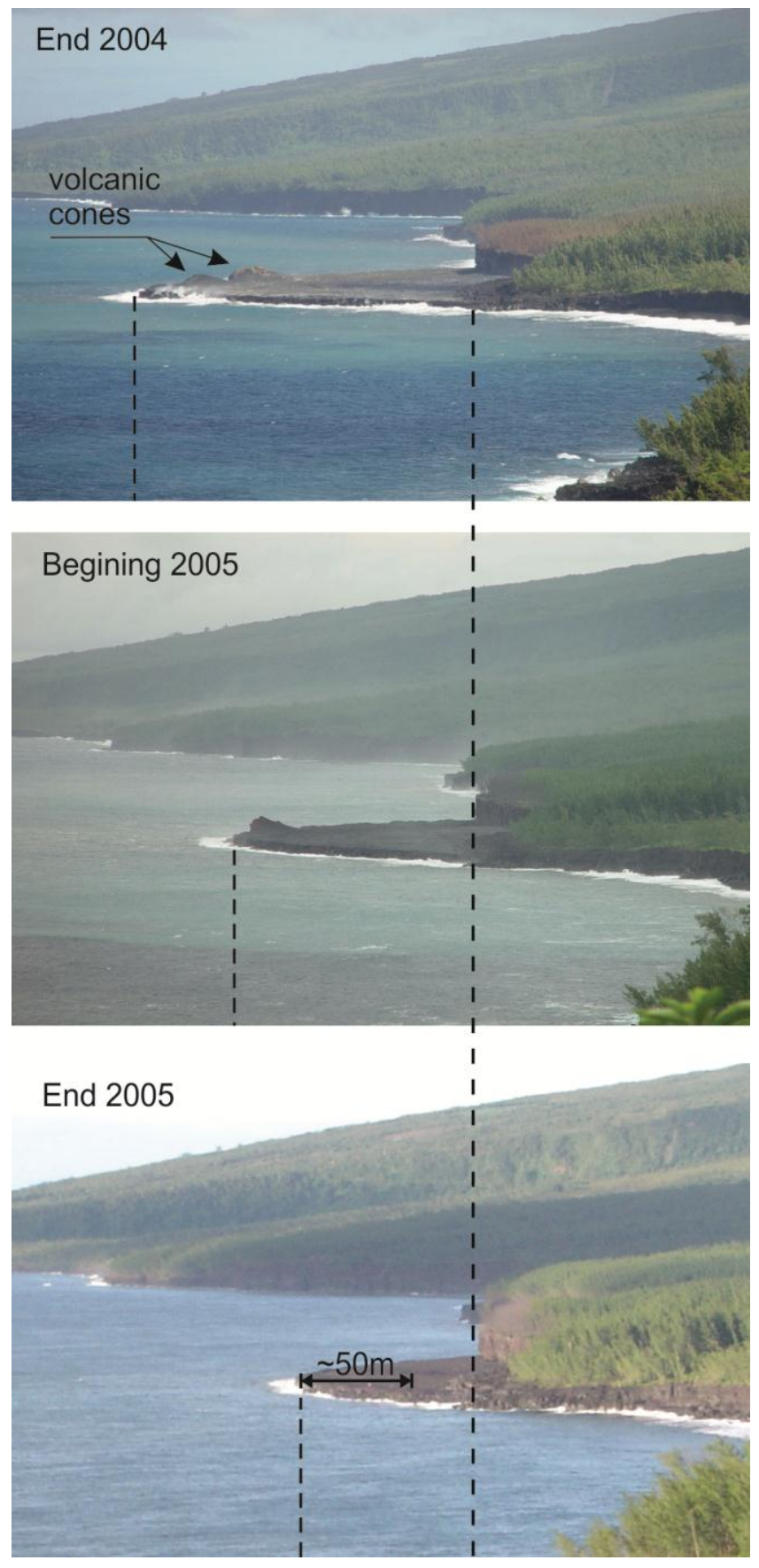




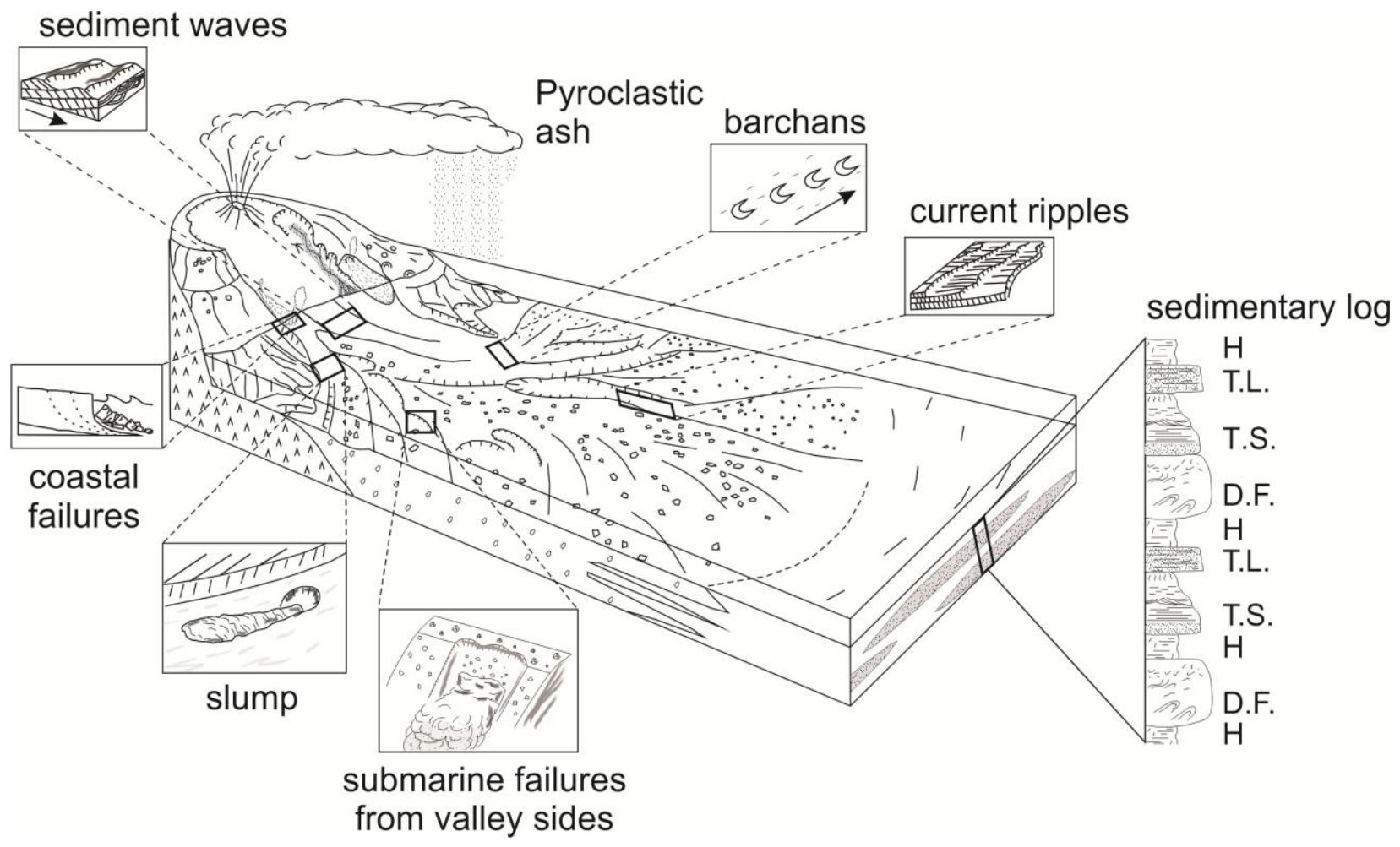

